\title{
How Early Diagenesis Reveals In Situ Biodegradation of Herbicides in Sediment
}

\author{
Devault Damien A. ${ }^{1}$, Delmotte Sébastien², Macarie Hervé3, \\ Dolfing Jan ${ }^{4}$ and Anschutz Pierre ${ }^{5}$ \\ ${ }^{1}$ Cemagref, Centre de Martinique, Pôle de Recherche Agro-environnemental \\ de la Martinique, Quartier Petit Morne, BP 214, 97285 Lamentin \\ ${ }^{2}$ MAD-Environnement, Allée des Demoiselles, 33170 Gradignan \\ ${ }^{3} I R D$, UMR IMEP (CNRS / IRD), Aix-Marseille Université, Faculté des \\ Sciences de St. Jérôme, Boîte 441, 13397 Marseille cedex 20 \\ ${ }^{4}$ School of Civil Engineering and Geosciences, Newcastle University \\ Newcastle upon Tyne, NE1 7RU England \\ ${ }^{5}$ UMR Environnements et Paléo-environnements OCéaniques (EPOC) \\ Université Bordeaux 1, 33405 Talence \\ 1,2,3,5 France \\ 4 United Kingdom
}

\section{Introduction}

Globalisation of environment contamination is one of the actual major concerns. Concentrated in the developed countries during 1950s and 1960s, the use of pesticides, particularly the organic ones, has dramatically increased since 1970s (Alavanja, 2009). Agro chemistry expansion is parallel to diffusion of other technologies involving molecules proved to be environmental contaminants. Progressive prohibition of indiscriminate use of chemicals, considered as a threat for human and environmental health, highlights their persistence and their ubiquity. Although for partly natural contaminants like polycyclic aromatic hydrocarbons, the question is to dissociate the natural input (fires...) from the anthropogenic one; the synthesised molecules like herbicides do not give rise to such a controversy. However, understanding their flux from contaminated parcels and their fate in the environment requires historical overview that can be achieved through coring. In order to be informative coring needs to be performed on quiescent, biotic and unconsolidated growing matrix and for these reasons sediments are the most often sampled.

Coring is performed with the following five aims:

1. Defining the origin of a contamination leaning on the pollutant threat accompaniment as in source investigation (Koistinen et al., 1997) as in land use concern, distinguishing agricultural, urban or industrial input (Feng et al., 1998; Secco et al., 2005).

2. Establishing the contamination source (runoff, atmospheric deposition), especially for arctic areas due to cold condensation (Rawn et al., 2001; Macdonald et al., 2005, de Wit et al., 2006). For herbicide monitoring, such studies are scarce: even if Henry's constant are in favour to volatilization, atmospheric transport enhances photolysis. 
3. Performing a retrospective analysis of dated sediment cores to evaluate the historical fluxes since the 1950s (Harrad et al., 1994; Hong et al., 2003), especially to segregate the anthropic impact to (bio) geochemical trends (Connor \& Thomas, 2003). As, Nylund et al. (1992) said: "retrospective time trends are essential in the judgement of a pollution situation".

4. Defining the state on the contaminant persistence in the environment. This consists to determine its half life and to estimate the time needed for the exportation of residues from an upstream watershed (Covaci et al., 2005). This aim can give information on the efficiency of a decision to ban pesticide use.

5. Estimating the fate of organic pollutants in sediment (Eganhouse et al., 2000; Devault et al., 2009).

Coring is used to answer to the major question of the fate of contaminants, in molecule as well as in watershed scale. Instead of heavy metals the presence of which can only be discussed in terms of speciation, organic pollutants may suffer profound transformations up to the point of complete mineralization (Bartha, 1971; Ficher, 1974; Pignatello, 1992). Briefly, the alteration of their chemical structure may be the result of physico-chemical reactions (photolysis, cryolysis hydrolysis...) and/or biodegradation (e.g. Grover et al., 1997 on trifluralin, Roberts et al., 2002 on paraquat, Krutz et al., 2010 on s-triazines...).

In soil and sediment, photolysis only occurs on the surface and could be so regarded as marginal in comparison to biodegradation and hydrolysis, although there are notorious exceptions such as for example in the case of the herbicide trifluralin that is strongly vulnerable to sunlight (Grover et al., 1997). Photolysis may also be promoted by the presence of MnVI and Fe(III) but their concentrations are usually quickly reduced with depth (Knights et al., 2003). In immerged sediments, the role of hydrolysis in herbicide alteration may be maximized, but generally speaking, hydrolysis is rarely fast enough to be the predominant alteration process. In such wet environment, contrarily to soil where dryness event may restrain microbial flora development, biodegradation appears as the main process responsible for the alteration of the herbicide structure although some authors have suggested that the supposed low temperatures in these environments and their negative effect on the microbial activity should result in an absence of important decrease of their herbicide stock (Mortensen and Jacobsen, 2004; Grimalt et al., 2004). This however is not supported by experimental work. In sediment environment, diffusion of dissolved oxygen used as electron acceptor by micro organisms is limited by early compaction process and local consumption. Then, anaerobic conditions are usually dominant. In absence of oxygen, bacteria can use several alternative electron acceptors. This results in a stratification of the bacterial communities corresponding to the successive use of specific electron acceptors in order of energy yields, which in turns influences the microbial degradation of organic compounds, in particular the halogenated aromatic ones. Stratification can be significantly perturbed by benthic biota, enhancing the sediment part where early diagenesis occurs.

The aim of the present chapter is to provide an overview on a pivotal process for the fate of herbicide residues -but generally underestimate even not taken into account.

\section{Early diagenesis}

\subsection{Introduction}

Sediments record earth surface activities, such as climate or anthropogenic impact on the environment. Before burial, however, particles deposited in aqueous environments 
experience transformations called early diagenesis (Berner, 1980), which modify the initial recording. Biological activity of benthic micro- and macro-organisms supports the mechanisms of early diagenetic reactions. Biogeochemical processes in the first centimetres below the sediment/water interface change the chemistry and the mineralogy of sediments. Major diagenetic reactions are processes of oxidation/reduction, dissolution/precipitation, adsorption/desorption and changes in speciation. The nature and amplitude of early diagenetic processes depend mostly on physico-chemical properties of overlying waters and on organic matter flux towards the bottom. The amount of knowledge on early diagenesis processes is the result of 30 years of science, including pioneer works of Froelich et al. (1979) on the vertical sequence of red-ox reactions, Berner (1980) on the transport-reaction coupling, and Aller (1980) on the influence of macro-fauna on reactions and fluxes.

\subsection{Biogeochemical processes in modern sediments}

Modern sediments comprise the first decimetres below the sediment-water interface. This compartment contains organic carbon imported from the overlying water column or formed by benthic producers. Early diagenesis reactions are linked to organic matter mineralization. The mineralization of organic carbon alters the initial mineralogy and chemistry of deposited particles and interstitial waters, and determines the benthic cycle of redox species and the fate of sedimentary organic matter. Oxidation of organic matter requires an electron acceptor. The preferential use of the electron acceptor that yields the highest amount of free energy in the terminal step of the bacterially-mediated oxidation of organic matter constitutes a long-standing paradigm in biogeochemistry (Froelich et al., 1979; Postma \& Jakobsen, 1996) (Table 2, Fig. 1). In undisturbed sediments, this paradigm is reflected in well documented vertical changes in pore waters and particles chemistry (Fig. 2).

The $\mathrm{O}_{2}$ concentration decreases rapidly below the sediment surface. Nitrate increases in the oxygen containing layer and then decreases below. The disappearance of oxygen and nitrate is accompanied by a decline of the Mn-oxide content and an increase in dissolved manganese, followed deeper down by an increase in dissolved iron. Total sulphur content increases with depth, whereas sulphate concentration decreases. Deeper down, methane can reach high concentrations, particularly when sulphate reaches a zero concentration, which is common in fresh water sediments. This distribution follows the depth sequence of diagenetic reactions. Oxygen is reduced near the sediment-water interface, followed by the reduction of nitrate and manganese oxide, then reactive iron oxide $\left(\mathrm{Fe}_{\mathrm{ASC}}\right)$, sulphate, and carbon dioxide (Froelich et al., 1979, Postma and Jakobsen, 1996).

Chemical changes produce vertical gradients. Gradients generate fluxes within the sediment and across the sediment/water interface. Transport mechanisms are diffusion, advection and mixing. Molecular diffusion is driven by concentration gradients and can be quantified using Fick's first law. It is a spontaneous processes carrying species downgradient, that depends on temperature, gradient, porosity and the nature of the diffusing species. In deep sediments it represents the main pathway for the transport of dissolved compounds. Bio diffusion reflects the activity of benthic organisms that adds to passive diffusion in surface sediments. Mixing by bioturbation produces a transport of particles. Then, the relative positions of reducing and oxidizing sediment components is shifted. As pointed out by Aller (1994), such disturbed systems could be better conceptualized as a spatially and temporally changing mosaic of redox reactions.

The $\mathrm{O}_{2}$ consumption is attributed to oxic degradation of organic matter (reaction 1, Tab. 3) and the re-oxidation of products from the anaerobic degradation of organic matter (Canfield 


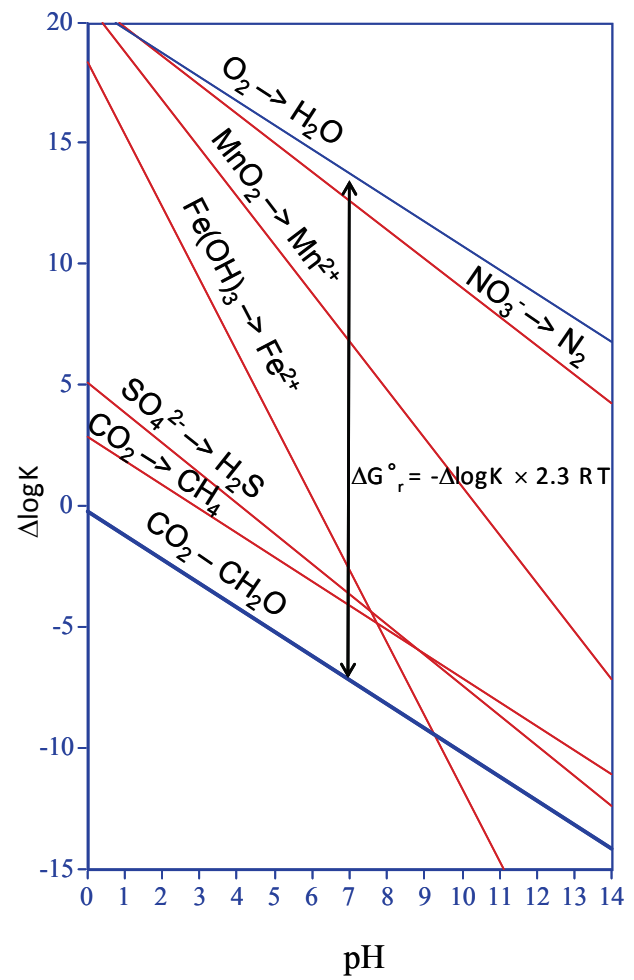

Fig. 1. $\Delta \log \mathrm{K}$ vs. $\mathrm{pH}$ plots for selected half redox reactions involved in organic matter oxidation. $\Delta \log \mathrm{K}$ is the total free energy at a given $\mathrm{pH}$ (see Table 1 ). The vertical distance between the line of $\left(\mathrm{CH}_{2} \mathrm{O}\right)$ oxidation to $\mathrm{CO}_{2}$ and any line representing reduction of electron acceptors gives the energy yield. The sequence of redox reaction can be deduced from this graph. Thermodynamically favourable secondary reactions can be deduced also from this graph. Temperature: $20^{\circ} \mathrm{C}$

Element aqueous phase particulate phase

\begin{tabular}{|c|c|c|}
\hline $\mathrm{C}$ & $\begin{array}{l}\mathrm{C}^{(+\mathrm{IV})} \mathrm{O}_{2}, \mathrm{HC}^{(+\mathrm{IV})} \mathrm{O}_{3^{-}}, \mathrm{C}^{(+\mathrm{IV})} \mathrm{O}_{3^{2-}}, \\
\mathrm{C}^{(-\mathrm{IV})} \mathrm{H}_{4}, \mathrm{C}(-\mathrm{IV}) \text { à }(+\mathrm{IV})-\text { org }\end{array}$ & $\mathrm{C}(-\mathrm{IV})$ to $(+\mathrm{IV})-$ org, $\mathrm{CaC}^{(+\mathrm{IV})} \mathrm{O}_{3}$ \\
\hline $\mathrm{N}$ & \multicolumn{2}{|c|}{ 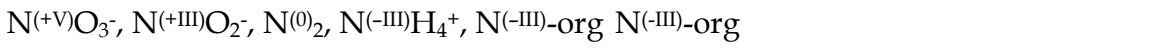 } \\
\hline $\mathrm{O}$ & \multicolumn{2}{|c|}{$\left.\mathrm{O}^{(0)}\right)_{2}, \mathrm{H}_{2} \mathrm{O}(-\mathrm{II})$} \\
\hline $\mathrm{P}(+\mathrm{V})$ & $\mathrm{PO}_{4}^{3-}, \mathrm{HPO}_{4}^{2-}, \mathrm{H}_{2} \mathrm{PO}_{4}^{-}$ & $\begin{array}{l}\text { P-org, phosphates (apatite, } \\
\text { francolite...), adsorbed-PO }{ }_{4}^{3-}\end{array}$ \\
\hline S & $\mathrm{S}(+\mathrm{VI}) \mathrm{O}_{4}{ }^{2-}, \mathrm{H}_{2} \mathrm{~S}(-\mathrm{II}), \mathrm{S}(-\mathrm{II}) \mathrm{H}^{-}$ & sulfides(-II) \\
\hline $\mathrm{Fe}$ & $\mathrm{Fe}^{2+}$ & $\mathrm{Fe}^{(+\mathrm{III})}$-oxides, $\mathrm{Fe}^{(+\mathrm{II})}$-sulfides, $\mathrm{Fe}^{(+\mathrm{II})} \mathrm{CO}_{3}$ \\
\hline Mn & $\mathrm{Mn}^{2+}$ & 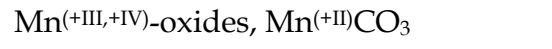 \\
\hline
\end{tabular}

Table 1. Major dissolved and particulate redox compounds involved in early diagenesis processes. The redox state appears in brackets 


\begin{tabular}{llll}
\hline $1 / 4 \mathrm{CO}_{2}+\mathrm{H}^{+}+\mathrm{e}^{-}$ & $=$ & $1 / 4 \mathrm{CH}_{2} \mathrm{O}+1 / 4 \mathrm{H}_{2} \mathrm{O}$ & -0.20 \\
$1 / 4 \mathrm{O}_{2}+\mathrm{H}^{+}+\mathrm{e}^{-}$ & $=$ & $1 / 2 \mathrm{H}_{2} \mathrm{O}$ & +20.75 \\
$1 / 5 \mathrm{NO}_{3}+6 / 5 \mathrm{H}^{+}+\mathrm{e}^{-}$ & $=$ & $1 / 10 \mathrm{~N}_{2}+3 / 5 \mathrm{H}_{2} \mathrm{O}$ & +21.05 \\
$1 / 8 \mathrm{NO}_{3}+5 / 4 \mathrm{H}^{+}+\mathrm{e}^{-}$ & $=$ & $1 / 8 \mathrm{NH}_{4}+3 / 8 \mathrm{H}_{2} \mathrm{O}$ & +14.90 \\
$1 / 2 \mathrm{MnO}_{2}+2 \mathrm{H}^{+}+\mathrm{e}^{-}$ & $=$ & $1 / 2 \mathrm{Mn}^{2+}+\mathrm{H}_{2} \mathrm{O}$ & +20.80 \\
$\mathrm{MnO}(\mathrm{OH})+3 \mathrm{H}^{+}+\mathrm{e}^{-}$ & $=$ & $\mathrm{Mn}^{2+}+2 \mathrm{H}_{2} \mathrm{O}$ & +18.31 \\
$\mathrm{Fe}(\mathrm{OH})_{3}+3 \mathrm{H}^{+}+\mathrm{e}^{-}$ & $=$ & $\mathrm{Fe}^{2+}+3 \mathrm{H}_{2} \mathrm{O}$ & +13.60 \\
$\mathrm{FeO}(\mathrm{OH})+3 \mathrm{H}^{+}+\mathrm{e}^{-}$ & $=$ & $\mathrm{Fe}^{2+}+2 \mathrm{H}_{2} \mathrm{O}$ & +5.08 \\
$1 / 8 \mathrm{SO}_{4}^{2-}+5 / 4 \mathrm{H}^{+}+\mathrm{e}^{-}$ & $=$ & $1 / 8 \mathrm{H}_{2} \mathrm{~S}+1 / 2 \mathrm{H}_{2} \mathrm{O}$ & +2.87 \\
$1 / 8 \mathrm{CO}_{2}+\mathrm{H}^{+}+\mathrm{e}^{-}$ & $=$ & $1 / 8 \mathrm{CH}_{4}+1 / 4 \mathrm{H}_{2} \mathrm{O}$ & \\
\hline
\end{tabular}

Table 2. Redox half-reactions linked to organic carbon oxidation and their $\log \mathrm{K}$ at $25^{\circ} \mathrm{C}$. Free energy data are from Stumm \& Morgan (1996), in kJ/mol : $\mathrm{e}^{--}=0 ; \mathrm{H}^{+}=0 ; \mathrm{H}_{2} \mathrm{O}=-237.18$;

$\mathrm{CO}_{2}=-394.37 ; \mathrm{CH}_{2} \mathrm{O}=-152.63 ; \mathrm{O}_{2}=0 ; \mathrm{NO}_{3}^{-}=-111.3 ; \mathrm{N}_{2}=0 ; \mathrm{NH}_{4}{ }^{+}=-79.37 ; \mathrm{IO}_{3}^{-}=-128 ; \mathrm{I}^{-}=-$ $51.59 ; \mathrm{MnO}_{2}=-465.1 ; \mathrm{MnO}(\mathrm{OH})=-557.7 ; \mathrm{Mn}^{2+}=-228 ; \mathrm{Fe}(\mathrm{OH})_{3}=-699 ; \mathrm{FeO}(\mathrm{OH})=-488.6$; $\mathrm{Fe}^{2+}=-91.84 ; \mathrm{SO}_{4}{ }^{2-}=-744.6 ; \mathrm{H}_{2} \mathrm{~S}=-27.87 ; \mathrm{CH}_{4}=-50.79$. Example of $\operatorname{logK}$ calculation from the first reaction: $\log \mathrm{K}=-\left(\Delta \mathrm{G}^{\circ} \mathrm{r}\right) / \mathrm{RT} \ln (10)=-0.20$, with $\mathrm{R}=8.314 \mathrm{~J} / \mathrm{mol} / \mathrm{K}, \mathrm{T}=298 \mathrm{~K}$, and $\Delta \mathrm{G}^{\circ} \mathrm{r}$ $=1 / 4(-152.63)+1 / 4(-237.18)-1 / 4(-394.37)=1140 \mathrm{~J} / \mathrm{mol}$.
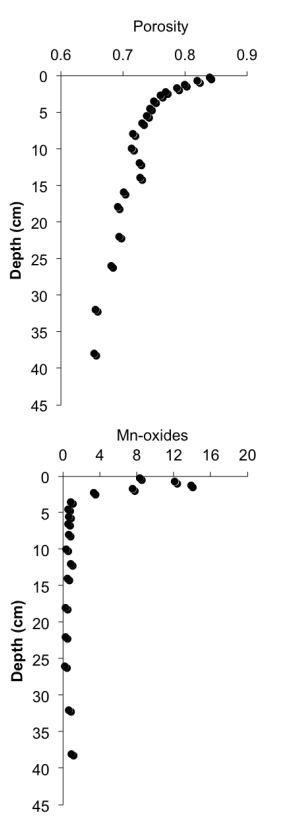
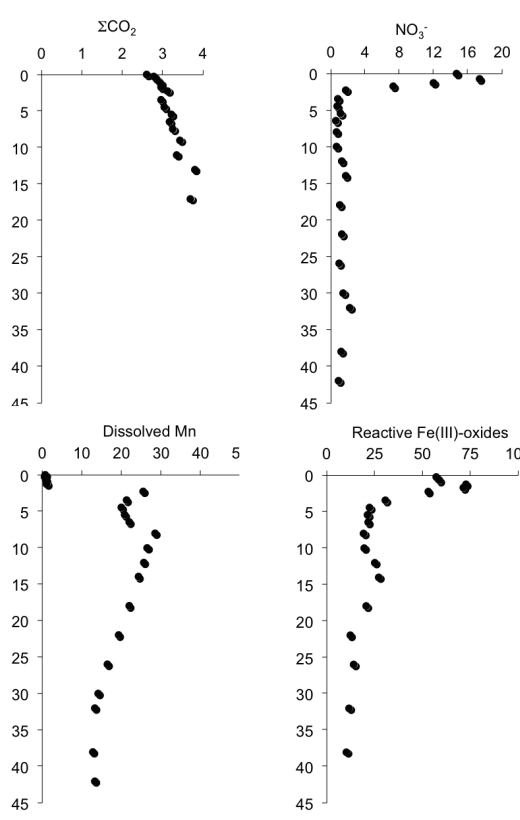

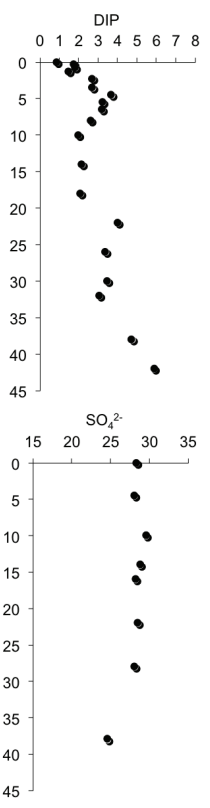

Fig. 2. (caption corrected): . Concentration vs. depth profile of dissolved and particulate compounds involved during early diagenesis and porosity. Example of a sediment collected in the Bay of Biscay at $550 \mathrm{~m}$ water depth. The zero depth corresponds to the sediment/water interface (modified from Hyacinthe et al., 2001). DIP = dissolved inorganic phosphorus/ Mn-oxides and reactive Fe(III)-oxides have been extracted from the solid fraction with an ascorbate reagent (Anschutz et al., 2005). Dissolved species are in $\mu \mathrm{M}$, except sulphate in $\mathrm{mM}$. Particulate oxides are in $\mu \mathrm{mol} / \mathrm{g}$. 
et al., 1993). The observed thickness of the oxic layer depends directly on flux of labile organic carbon in the surface sediment.

The peak of nitrate in the oxic layer is attributed to the succession of reactions that lead to the bacterial nitrification of organic $\mathrm{N}$ (reaction 1, Tab. 3) or ammonia that diffuses from below (reaction 7, Tab. 3). The consumption of nitrate below the oxic layer is due to the bacterial denitrification (reaction 2, Tab. 3). $\mathrm{NH}_{4}{ }^{+}$is produced from anaerobic mineralization of organic-N (reactions 4, 5 and 6, Tab. 3). The production of dissolved $\mathrm{Mn}^{2+}$ and $\mathrm{Fe}^{2+}$ in anaerobic sediments is attributed to the dissimilate reduction of manganese and iron oxides by bacteria (reactions 3 and 4, Tab. 3). The peak of Mn-oxides can be attributed to detrital Mn-oxides and authigenic Mn-oxides precipitate from the oxidation of dissolved $\mathrm{Mn}^{2+}$ that diffuses from below (Sundby, 1977). The concentration of Mn-oxides decreases abruptly below the oxic front, reaching values close to zero, which indicate that the Mn-oxides are totally reduced. The distribution of Fe-oxides shows highest concentrations near the oxic layer and decreases below. Amorphous manganese and iron oxide phases may be used as terminal electron acceptors in bacterial oxidation of organic carbon or they may react with reduced sulphur to form FeS.

The presence of particulate sulphur in continental margin sediments can be mostly attributed to authigenic iron-sulphide minerals that precipitate during the degradation of organic matter by sulphate-reduction (reaction 5, Tab. 3) (Berner, 1971; Jørgensen, 1982). The first compound that generally forms is amorphous FeS. It is subsequently converted to more crystalline pyrite (Berner, 1970; Schoonen and Barnes, 1991).

Within all possible reactions, recent studies attach more and more importance to metal oxides, particularly for their role in the benthic cycle of nitrogen (Luther et al., 1997; Aller et al., 1998; Anschutz et al., 2000). It has been pointed out by several authors that the reduction of Mn-oxide by diffusing ammonia could be an important process of dinitrogen production (e.g. Hulth et al., 1999; Anschutz et al., 2000). This pathway could interfere with dissimilatory Mn-reduction. Dissolved Mn(II) can be oxidized by nitrate (Aller, 1990; Schulz et al., 1994; Murray et al., 1995; Luther et al., 1997) or by iodate (Anschutz et al., 2000). Anaerobic nitrate production has been observed in several marine sediments (Aller et al., 1998; Anschutz et al., 1998; Mortimer et al., 2002 ; Deflandre et al., 2002; Chaillou et al., 2007). This process is due to oxidation of ammonia by $\mathrm{Mn}(\mathrm{III})$-oxides. Iron oxide presents a wide speciation variety. The most labile fraction serves as oxidant for reduced compounds like dissolved ones (Canfield et al., 1992). All these alternatives or secondary reactions are thermodynamically favourable.

\subsection{Interactions between benthic organisms and the sediment}

In broad definition, bioturbation is the whole spectrum of physical, chemical and biological modifications of soils and sediments induced by the biological activities of all kind of living organisms (fauna, microbes, plants roots). In its strict sense, as it was employed in the first studies of bioturbation in marine sediments (Gray, 1974; Rhoads, 1974; Self and Jumars, 1978; Aller, 1977, 1980, 1982), it represents the sediment reworking and particularly the particles dispersal induced by the activities of burrowing animals. The bioturbation counterpart for solutes is called bio-irrigation, which designates the enhancement of solute transport in sediments by animal activities as gallery flushing. Even if Darwin had already shown the importance of worms activities in soils formation and functioning (Darwin, 1881), the primordial role of bioturbation and bio-irrigation in biogeochemical functioning of aquatic sediments was recently put forward in 1970'. 
Bioturbation is now considered as a major process which drives diagenetic reactions, benthic landforms formation and biogeochemical cycles at the global scale although local effects and the scale of the living organisms (Meysman et al., 2006 a).

Tracerconcentrations
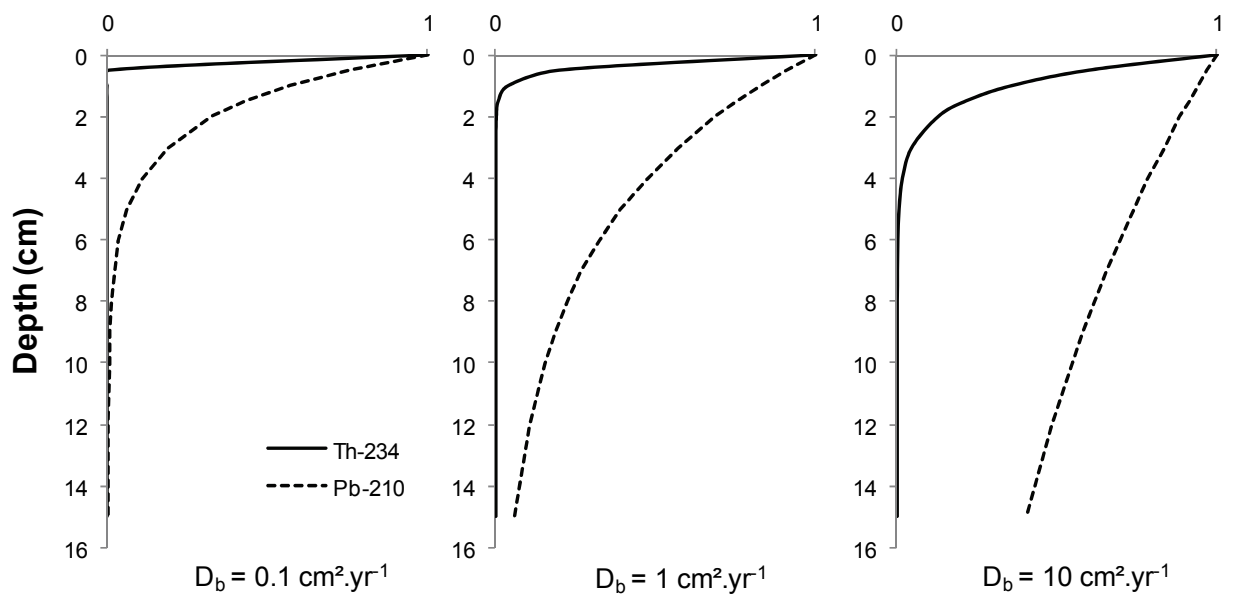

Fig. 3. Short-lived (Th-234) and long-lived ( $\mathrm{Pb}-230)$ tracers profiles under various

bioturbation intensities. These profiles are obtained in applying the biodiffusion model with a sedimentation rate of $0.1 \mathrm{~cm} . \mathrm{yr}^{-1}$.

In a general way, biological mechanisms of sediment reworking results from the activities of feeding, protection and reproduction of benthic animals. They burrow, excavate sediment and they dig galleries which communicate with overlying water. They often produce biogenic structures as mucus secretion and faecal pellets deposits resulting from ingestionegestion of particles. They also ventilate their galleries to renew water. As consequences:

i. bioturbation generates biological transport of particles between different reactive zones in sediment on distances varying in the range from the millimetre to the metre (a classical average depth of bioturbation is about $10 \mathrm{~cm}$, Boudreau, 2004);

ii. as a result of (i), bioturbation generates transport of micro-organisms associated with sediments between different reactive zones, modifies the bio-accessibility of nutrients and organic compounds and stimulates competition between bacterial groups by selective grazing (Aller, 1982; Stief and De Beer, 2002; Mermillod Blondin et al., 2003; Thullner et al., 2005);

iii. it modifies the sediment composition, e.g. in enriching the faecal pellets with organic matter as a result of the selective feeding (Brinkhurst et al., 1972; Davis, 1974);

iv. it increases exchange surface with water column and modifies sediment physical properties as porosity, permeability, compaction and stability (Rhoads, 1974; McCall and Fisher, 1980; Meadow and Tait, 1989; Sandness et al., 2000; DeDekere et al., 2001; Ciutat et al., 2006; Rasmussen et al., 1998). As they often actively irrigate their galleries by flushing, they enhance the exchange of solutes and particles between the sedimentary compartment and the free overlying water (Ciarelli et al., 1999, Meysman et al., 2006 b). 
Depth sequence of bacterially-mediated oxidation of organic matter (Froelich et al., 1979; De Lange, 1986)

(O.M. $=\mathrm{C}_{106} \mathrm{H}_{263} \mathrm{O}_{110} \mathrm{~N}_{16} \mathrm{P}$ )

Oxygen consumption by oxic respiration and nitrate production

$138 \mathrm{O}_{2}+$ O.M. $+18 \mathrm{HCO}_{3}{ }^{-} \rightarrow 124 \mathrm{CO}_{2}+16 \mathrm{NO}_{3}{ }^{-}+\mathrm{HPO}_{4}{ }^{2-}+140 \mathrm{H}_{2} \mathrm{O}$

Nitrate consumption by denitrification

94. $4 \mathrm{NO}_{3}{ }^{-}+$O.M. $\rightarrow 13.6 \mathrm{CO}_{2}+92.4 \mathrm{HCO}_{3}{ }^{-}+55.2 \mathrm{~N}_{2}+84.8 \mathrm{H}_{2} \mathrm{O}+\mathrm{HPO}_{4}{ }^{2-}$

Reduction of Mn-oxides by anaerobic respiration

$236 \mathrm{MnO}_{2}+$ O.M. $+364 \mathrm{CO}_{2}+104 \mathrm{H}_{2} \mathrm{O} \rightarrow 470 \mathrm{HCO}_{3}{ }^{-}+8 \mathrm{~N}_{2}+236 \mathrm{Mn}^{2+}+\mathrm{HPO}_{4}{ }^{2-}$

Reduction of Fe-oxides and production of ammonia

$424 \mathrm{FeOOH}+$ O.M. $+740 \mathrm{CO}_{2}+104 \mathrm{H}_{2} \mathrm{O} \rightarrow 846 \mathrm{HCO}_{3}{ }^{-}+424 \mathrm{Fe}^{2+}+16 \mathrm{NH}_{3}+\mathrm{HPO}_{4}{ }^{2-}$

Production of sulphide and ammonia by sulphatoreduction

$53 \mathrm{SO}_{4}^{2-}+\mathrm{O} . \mathrm{M} . \rightarrow 39 \mathrm{CO}_{2}+67 \mathrm{HCO}_{3}^{-}+16 \mathrm{NH}_{4}{ }^{+}+53 \mathrm{HS}^{-}+39 \mathrm{H}_{2} \mathrm{O}+\mathrm{HPO}_{4}{ }^{2-}$

Production of methane and ammonia by methanogenesis

O.M. $\rightarrow 53 \mathrm{CO}_{2}+53 \mathrm{CH}_{4}+16 \mathrm{NH}_{4}++\mathrm{HPO}_{4}{ }^{2-}$

Production of nitrate by nitrification

$\mathrm{NH}_{4}{ }^{+}+2 \mathrm{O}_{2} \rightarrow \mathrm{NO}_{3}{ }^{-}+2 \mathrm{H}^{+}+\mathrm{H}_{2} \mathrm{O}$

Oxidation of $\mathrm{Mn}^{2+}$ with oxygen

$2 \mathrm{Mn}^{2+}+\mathrm{O}_{2}+2 \mathrm{H}_{2} \mathrm{O} \rightarrow 2 \mathrm{MnO}_{2}+4 \mathrm{H}^{+}$

$4 \mathrm{Mn}^{2+}+\mathrm{O}_{2}+6 \mathrm{H}_{2} \mathrm{O} \rightarrow 4 \mathrm{MnOOH}+8 \mathrm{H}^{+}$

Oxidation of $\mathrm{Mn} 2+$ with nitrate

$5 \mathrm{Mn}^{2+}+2 \mathrm{NO}_{3}{ }^{-}+4 \mathrm{H}_{2} \mathrm{O} \rightarrow 5 \mathrm{MnO}_{2}+\mathrm{N}_{2}+8 \mathrm{H}^{+}$

$10 \mathrm{Mn}^{2+}+2 \mathrm{NO}_{3}{ }^{-}+14 \mathrm{H}_{2} \mathrm{O} \rightarrow 10 \mathrm{MnOOH}+\mathrm{N}_{2}+18 \mathrm{H}^{+}$

Oxidation of $\mathrm{Fe}^{2+}$ with nitrate

$5 \mathrm{Fe}^{2+}+\mathrm{NO}_{3}{ }^{-}+12 \mathrm{H}_{2} \mathrm{O} \rightarrow 5 \mathrm{Fe}(\mathrm{OH})_{3}+1 / 2 \mathrm{~N}_{2}+9 \mathrm{H}^{+}$

Oxidation of $\mathrm{Fe}^{2+}$ with Mn-oxides

$\mathrm{Fe}^{2+}+\mathrm{MnOOH}+\mathrm{H}_{2} \mathrm{O} \rightarrow \mathrm{Fe}(\mathrm{OH})_{3}+\mathrm{Mn}^{2+}$

$2 \mathrm{Fe}^{2+}+\mathrm{MnO}_{2}+4 \mathrm{H}_{2} \mathrm{O} \rightarrow 2 \mathrm{Fe}(\mathrm{OH})_{3}+\mathrm{Mn}^{2+}+2 \mathrm{H}^{+}$

Reduction of Mn-oxide with ammonia to give dinitrogen

$3 / 2 \mathrm{MnO}_{2}+\mathrm{NH}_{4}^{+}+2 \mathrm{H}^{+} \rightarrow 3 / 2 \mathrm{Mn}^{2+}+1 / 2 \mathrm{~N}_{2}+3 \mathrm{H}_{2} \mathrm{O}$

$3 \mathrm{MnOOH}+\mathrm{NH}_{4}^{+}+5 \mathrm{H}^{+} \rightarrow 3 \mathrm{Mn}^{2+}+1 / 2 \mathrm{~N}_{2}+6 \mathrm{H}_{2} \mathrm{O}$

Reduction of Mn-oxide with ammonia, production of nitrate

$8 \mathrm{MnOOH}+\mathrm{NH}_{4}{ }^{+}+14 \mathrm{H}^{+} \rightarrow 8 \mathrm{Mn}^{2+}+\mathrm{NO}_{3}{ }^{-}+13 \mathrm{H}_{2} \mathrm{O}$

$4 \mathrm{MnO}_{2}+\mathrm{NH}_{4}^{+}+6 \mathrm{H}^{+} \rightarrow 4 \mathrm{Mn}^{2+}+\mathrm{NO}_{3}^{-}+5 \mathrm{H}_{2} \mathrm{O}$

Other reactions: Precipitation and dissolution of $\mathrm{FeS}, \mathrm{CaCO}_{3}$ and $\mathrm{MnCO}_{3}$

Table 3. List of reactions considered in this work

The biogeochemical effects of bioturbation and bio-irrigation are multiples and often opposite: as an example, metallic contaminants tend to accumulate in sediment under the effect of particles reworking and ingestion whereas they are released to overlying water by the bio-irrigation activities (Banta and Anderson, 2003; Delmotte et al., 2007).

These effects also depend on: (i) the physico-chemical environmental conditions $(\mathrm{pH}$, oxygen, sediment composition, grain size, temperature...) although they modify them; (ii) the type of benthic species present that generates different reworking and exchange effects. The complex interplays between bioturbation and physico-chemical processes make the multiplicity of effects on biogeochemical functioning not straightforward to study. 
Quantification of sediment mixing is classically done using particle-tracers methods. They are based on the measurement of the vertical distribution of particle tracers within the sediment column. The underlying principle is that tracers initially deposited at the watersediment interface, or placed at some horizon within the sediment column (Gilbert et al. $2003 \mathrm{~b}$ ), are displaced due to action of benthic fauna. The establishment of vertical profiles of tracers concentration using different methods (sediment cores slicing, image analysis) allows to monitor the tracers displacements. Sediment reworking coefficients are then computed using mathematical models that are fitted to the vertical tracer profile. (Goldberg and Koide, 1962; Guinasso and Schink, 1975; Aller, 1982; Boudreau 1986a ; Boudreau 1986b ; Wheatcroft et al. 1990 ; Gerino, 1990; Delmotte et al., 2007 ; Meysman et al. 2007). Vertical mixing was traditionally evaluated using particle-reactive radionuclide such as $\mathrm{Pb}-210$ and Cs-137 in quantifying long-term (years to decade) and short-term mixing (week to month) (Robbins et al., 1977, Rice, 1986, Maire et al., 2008). More recently, conservative fluorescent particles were used to monitor the biological-induced displacements of sediment particles (Gerino, 1990; Ciutat et al., 2005). Other tracers have also been used such as pollen or Chlorophyll-a (Gerino et al., 1998; Maire et al. 2008). Some tracers are naturally deposited with a constant flux or a pulse (radionuclide, Chlorophyll-a) at the sediment-water interface whereas others are deposited by experimenters.

In the face of complexity and diversity of biological mixing processes, it is often assumed that when a sufficient number and variety of small-scale mixing events occur within a sediment interval they can be treated as random particle eddies and quantified in a mixing coefficient analogous to the physical eddy diffusion coefficient in a fluid. If we consider vertical mixing over a depth layer of thickness $L$, the governing tracer equation becomes:

$$
\frac{\partial C}{\partial t}=D_{b} \frac{\partial^{2} C}{\partial x^{2}}-\omega \frac{\partial C}{\partial x}-\lambda C
$$

where $x$ represents the depth into the sediment, $C$ is the concentration or activity of the selected tracer, $D_{b}$ is the bio diffusion coefficient, $\omega$ the burial velocity, and $\lambda$ the decay constant of the tracer ( $\lambda=0$ with a conservative tracer). Suitable solutions of this equation are fitted to tracer depth profiles, and from this, an optimal estimate for the bio diffusion coefficient $D_{b}$ is obtained.

A major inconsistency in this analogy is that the path length of particle motion is often both specific in orientation and large in size scale with respect to chemical or physical property gradients in the sediment. For instance, sediment particles from depth may be placed directly at the oxidized sediment-water interface without mixing with material in between. Moreover, there is an inaccuracy in the time length of sediment reworking. Meysman et al. (2003) concluded that the bio diffusion analogy can be theoretically justified when the intrinsic time and length scales of sediment reworking are much smaller than their observational counterparts. These authors concluded that in many cases, the application of the bio diffusion model is questionable from a theoretical point of view. Still, in practice, tracer profiles often look diffusive and the bio diffusion analogy is widely employed to analyze these profiles. Meysman et al. (2003) refer to this apparently contradictory situation as the 'bio diffusion paradox'.

Despite such conceptual inaccuracies, some insight into the consequences of reworking as compared to simple sedimentation can be gained from the analogy. The cases of a shortlived tracer (Th-234, $\mathrm{t}_{1 / 2}=24.1$ days) and a long-lived tracer $\left(\mathrm{Pb}-210 \mathrm{t}_{1 / 2}=22.3\right.$ years) under 
various bio diffusion intensities are illustrated in Fig 3. Steady-state profiles are represented. Regarding the model coefficients, we retained values in the range of the reported ones in literature. Values of $D_{b}$ varies from 0.01 to $30 \mathrm{~cm}^{2}$. $\mathrm{yr}^{-1}$ for marine environments (Aller, 1982), with values often in the order of 1 to $10 \mathrm{~cm}^{2} \cdot \mathrm{yr}^{-1}$. Values for freshwater environments vary in the same range (Delmotte, 2007). Sedimentation rates can be lower than $0.1 \mathrm{~cm} . \mathrm{yr}^{-1}$ in marine environments and greater than $10 \mathrm{~cm} \cdot \mathrm{yr}^{-1}$ in freshwater environments: a value of $0.1 \mathrm{~cm} . \mathrm{yr}^{-1}$ is retained.

With a small value of $D_{b}\left(0.1 \mathrm{~cm}^{2} . \mathrm{yr}^{-1}\right)$, the short-lived tracer profile shows a high decrease in the first millimetres whereas the tracer reaches a depth of $5 \mathrm{~cm}$ with a value 100 times greater. The long-lived tracer reaches $8 \mathrm{~cm}$ with the smaller bio diffusion value; its profile tends to homogenize on the first $10 \mathrm{~cm}$ with a high value of bio diffusion. These simulations show the importance of bioturbation in term of sediment mixing and displacement of reactive particles. They can be used to estimate the fate of diverse herbicides (labile or persistent) in bioturbated sediments.

Note that more complex models of bioturbation were developed to account for the transport of particles on long distances and simulate the effects of specific modes of bioturbation (e.g. Boudreau, 1986b; Wheatcroft, 1990; Delmotte et al., 2007, 2008).

Measurements of bio irrigation are based on tracer-methods too. Reactive or conservative tracers are often injected in the overlying water, and both the concentrations of the tracer in this compartment and in the sediments are monitored to be modelled. Application of solute transport models gives coefficients that reflect the intensity of bio irrigation. The simplest model consists in using the diffusion model with an enhancement factor of the molecular diffusion of the tracer. For instance, Wang and Matisoff (1997) reported a diffusion enhancement factor in the range from 2 to 5 by freshwater tubificids, which is a classical range of value for many irrigating organisms. Freshwater tubificids generate a water exchange of $25 \mathrm{~L} . \mathrm{m}^{-2} \cdot \mathrm{d}^{-1}$ (Woods, 1975), which is important but not massively compared to Nereis diversicolor (Muller, 1776) which may induce 1500 L.m-2.d-1 (Kristensen and Kostka,

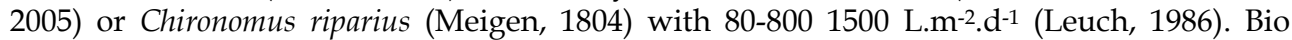
irrigation greatly enhances the flux of dissolved components at the water-sediment interface and their depth of penetration: as for bioturbation, this process seems primordial in the cycles of herbicides.

In order to understand the role of fauna activities in the degradation and storage of herbicides in sediment, the proper model would be a priori the early diagenesis of organic matter. Aller (1982) early proposed a conceptual model about the role of bioturbation and bio-irrigation on early diagenesis of organic matter (an adaptation is presented in Fig 4). This model fits well with the observed results of numerous studies.

Starting from the classical idealization of primary reactions of organic matter degradation, two major effects of benthos activities can be distinguished: (i) the geometry of solute diffusion is altered by the presence of burrows and the irrigation of the galleries. As a consequence, solute reactants and especially oxygen and nitrates are transported deeper in the sediments and an horizontal gradient of metabolic successions takes place in the walls of the galleries; (ii) burrow and faecal pellet formation alters reaction and solute diffusion geometries, creating a mosaic of biogeochemical microenvironments rather than a vertically stratified distribution. Moreover, it has been shown that ventilation of galleries creates a dynamic succession of aerobic and anaerobic conditions in the interstitial water (Aller, 1994, Sun et al., 2002; Gilbert et al, 2003a): in a first step, worms bring oxygen in their galleries by flushing with water from the overlying water column; in a second step, this oxygen is consumed by micro-organisms (aerobic oxidation) creating an oxygen depletion and an 


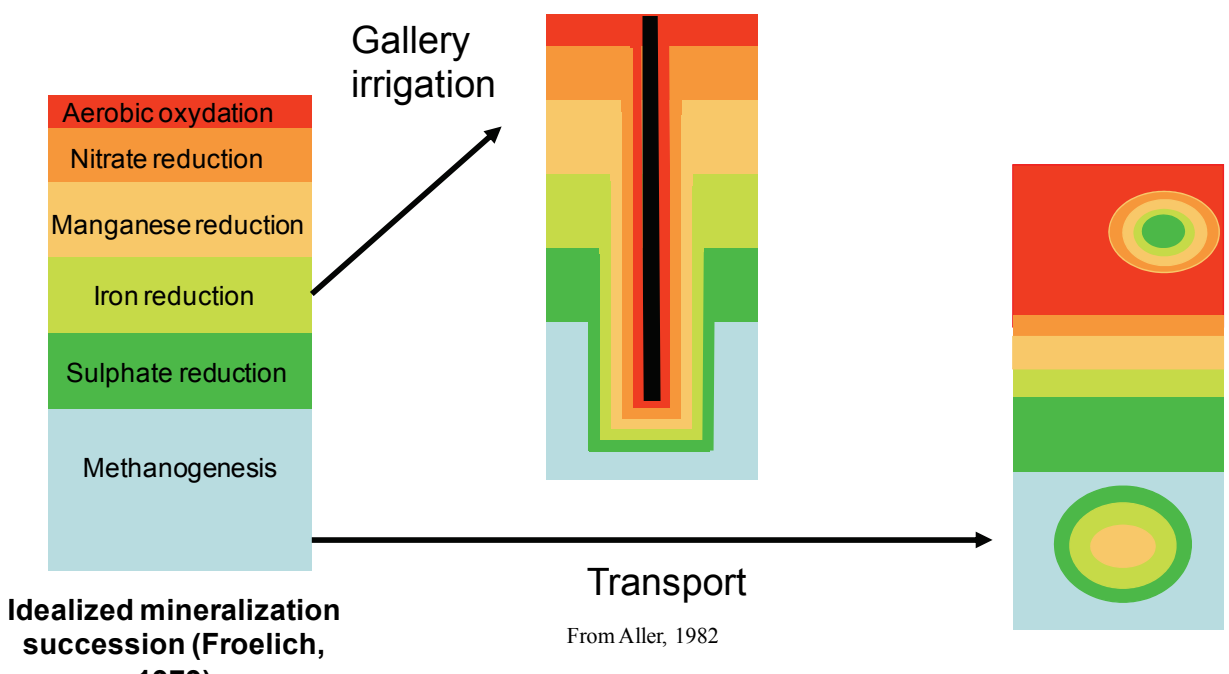

1979)

Fig. 4. Conceptual view of the effects of bioturbation and bio-irrigation on early diagenesis of organic matter.

enrichment of water with nitrates; in a third step, nitrates are consumed by micro-organisms in anaerobic conditions (denitrification); then, worms renew water bringing again oxygen. This redox oscillation in galleries enhances the organic matter mineralization by a factor 7 . Bioturbation and bio-irrigation deeply modify the biogeochemical functioning of sediments and hence the global geochemical cycles. As far as we know, the effects of bioturbation on herbicides geochemistry in sediments were not specifically addressed. Taking into account the living organisms bioturbating effects, on in-situ fate of this kind of contaminants, represents a challenge for the future studies and surely improves our comprehension of geochemical mechanisms of herbicides biodegradation. Numerical modelling of diagenesis of organic matter including the effects of bioturbation and bio irrigation really started in 1995 with a study of Van Cappellen and Wang. Since this paper, numerous models were presented (Boudreau, 1996; Soetaert et al., 1996; Meysman, 2001; Wijsman et al., 2002; Canavan et al., 2006; Delmotte, 2007). Such models allow exploring the influence of particular and solute transport on the numerous reactive processes, using bioturbation and bio irrigation coefficients obtained with tracer-methods. This represents a promising way to understand the fate of herbicides in bioturbated sediments.

\subsection{Conclusion}

The first decimetre of sediment below the sediment/water interface is an ordered and dynamic ecosystem. Benthic biogeochemical mechanisms are linked to the mineralisation of organic matter exported toward the sediment. Reactions and macro benthic activity determine the sedimentary cycle of carbon, redox species and all reactive components, including contaminants. All these phenomenon are related and depends on environmental properties, which vary in space and time. Therefore, studies on early diagenesis must take into account the complexity of the sedimentary environment and they need a multidisciplinary approach. 
A
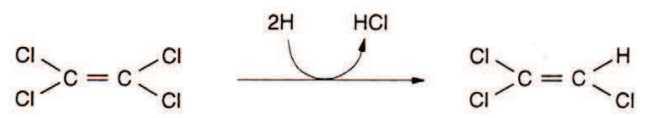

B

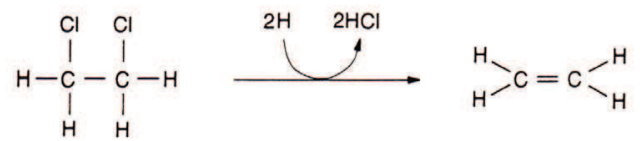

Fig. 5. Examples of two types of dehalorespiration: A. hydrogenolysis of tetrachlorethylene to trichloroethylene; $\mathrm{B}$. dihaloelimination of 1,2-dichloroethane to ethene.

\section{Microbiological degradation in sediment condition}

Herbicide degradation pathways are as various as herbicides are numerous and their chemical structure different.

Many of them, however frequently contain chlorine or bromine groups. Typical examples are synthesized plant hormone (2,4-dichlorophenoxyacetic acid, 2,3,6-trichlorobenzoic acid...), pentachlorophenol, triazines, chloroacetanilides, hydroxy-benzonitriles, some substituted ureas (chlortoluron...) and sulfonylureas (chlorsulfuron...), diphenyl-ethers (bromofénoxime, diclofop-methyl) and pyridylphenylethers (clodinafop-propargyl) (Häggblom and Bossert, 2003; BCPC, 2007). Microorganisms have evolved a variety of metabolic strategies for cleaving the carbon halogen bond, including reductive dechlorination (Dolfing and Tiedje, 1986; Mohn and Tiedje, 1992). Reductive dechlorination is considered the predominant process in the anaerobic transformation of halogenated compounds. Although it is also a strategy used by aerobic microorganisms, reductive dehalogenation is almost exclusively observed in anaerobic environments where both aliphatic and aromatic organohalides can function as terminal electron acceptors in an anaerobic respiration process termed (de)halorespiration (Dolfing 1990; Maphosa et al. 2010). Two types of dehalorespiration can be distinguished: hydrogenolysis and dihaloelimination (Fig. 5). Both require molecular hydrogen or some other source of reducing equivalents, and both are highly exergonic. Values for the $\Delta \mathrm{G}^{\mathrm{o}^{\prime}}$ of reductive dechlorination (hydrogenolysis) of halogenated compounds range from -130 to $-180 \mathrm{~kJ} . \mathrm{mol}^{-1}$ of halogen removed (Dolfing, 2003), corresponding to redox potentials $\left(\mathrm{E}_{\mathrm{o}}^{\prime}\right)$ of +260 to +480 $\mathrm{mV}$. This is comparable to the value for the redox couple $\mathrm{NO}_{3}^{-} / \mathrm{NO}_{2^{-}}\left(\mathrm{E}^{\prime}{ }_{\mathrm{o}}=+433 \mathrm{mV}\right)$, and substantially higher than the values for sulphate $\left(\mathrm{SO}_{4}^{2-} / \mathrm{HS} ; \mathrm{E}_{\mathrm{o}}^{\prime}=-217 \mathrm{mV}\right)$ and bicarbonate $\left(\mathrm{HCO}_{3}-/ \mathrm{CH}_{4} ; \mathrm{E}_{\mathrm{o}}^{\prime}=-238 \mathrm{mV}\right.$ ) (Dolfing et al. 2008), which suggests that dehalogenating organisms will outcompete sulphate reducers and methanogens for reducing equivalents when these are rate limiting. Thus there are no thermodynamic reasons why halogenated pesticides and other organohalides should not be biodegradable in the sulphate reducing and methanogenic layers of anaerobic sediments. There may well be ecophysiological reasons though. One of them could be that microorganisms simply not yet have had enough time to evolve the appropriate enzyme systems to catalyze and benefit from the dechlorination of halogenated pesticides. Although halogenated compounds per se are not necessarily xenobiotic, many chlorinated pesticides are. Chlorinated compounds tend to be fairly hydrophobic, and usually adsorb strongly to the sediment matrix. Thus the impetus for microbes to develop mechanisms to harness the energy locked up in these compounds is weak. Under those conditions fortuitous, co-metabolic conversion may well be the most 
prevalent route (van Eekert et al. 1999). Methanogenic archaea, which obtain energy for growth by converting hydrogen and acetate into methane, are for example able to degrade many organochlorines including pesticides (e.g. Jablonski \& Ferry, 1992; Jablonski et al. 1996), because some of the co-factors involved in methane formation can fortuitously dechlorinate them. The methanogens have however no mechanism to harness the energy of the latter reaction. Co-metabolic transformation of halogenated compounds is typically much slower than (de)halorespiration (Löffler et al. 1999).

The $\Delta \mathrm{G}^{\circ}$ values quoted above are for standard conditions: $\mathrm{pH}=7,25^{\circ} \mathrm{C}$, concentrations of substrates and products at $1 \mathrm{~mol}$ per litre, and gases at a partial pressure of $1 \mathrm{~atm}$ (100 000 $\mathrm{Pa}$ ). Environmental conditions are generally different from that. This is considered in $\Delta \mathrm{G}$ values. The rule of thumb for the conversion from $\Delta \mathrm{G}^{\mathrm{o}^{\prime}}$ to $\Delta \mathrm{G}$ values in reductive dechlorination reactions is that every 10 -fold change in concentration results in an adjustment of $5.7 \mathrm{~kJ} /$ reaction. Thus, for example, a 100 fold lower product concentration (e.g. [Cl-] is $10 \mathrm{mM}$ rather than $1 \mathrm{M}$ ) results in a $11.4 \mathrm{~kJ}$ lower ("more exergonic") $\Delta \mathrm{G}$ value, while a $\mathrm{pH}$ of 6 rather than 7 results in a 5.7 higher ("less exergonic") $\Delta \mathrm{G}$ value. Molecular hydrogen levels in methanogenic sediments are generally in the range of 10 to $100 \mathrm{~Pa}$; this results in adjustments of $\sim 17-23 \mathrm{~kJ}$ per reaction. It seems reasonable to assume equimolar concentrations of chlorinated pesticides (e.g. hexachlorobenzene) and their less halogenated dechlorination product (e.g. pentachlorobenzene), but even if the concentration of the product would be 1000 fold higher than the concentration of the substrate the adjustment would still be only $17 \mathrm{~kJ} . \mathrm{mol}^{-1}$. Given the fact that for example $\Delta \mathrm{G}^{\mathrm{o}^{\prime}}$ for the reaction hexachlorobenzene $+\mathrm{H}_{2} \rightarrow$ pentachlorobenzene $+\mathrm{H}^{+}+\mathrm{Cl}^{-}$is $-171.4 \mathrm{~kJ}$ per reaction (Dolfing and Harrison 1992) such adjustments are relatively minor, and it is safe to conclude that reductive dechlorination would remain exergonic under environmentally relevant conditions. Microorganisms in anoxic methanogenic sediments function at $\Delta \mathrm{G}$ values of -10 to $-20 \mathrm{~kJ}$ per reaction (Hoehler et al 2001).

Whereas microbiologists traditionally evaluate the thermodynamics of environmentally relevant reactions in terms of $\Delta \mathrm{G}^{\mathrm{o}^{\prime}}$ values, that is at $\mathrm{pH}=7$, chemists generally express redox half-reactions in terms of $\log \mathrm{K}$ values (e.g. Table 2 ) at $\mathrm{pH}=0$. Following the latter convention Table 5 lists the $\log \mathrm{K}$ values of all reductive dechlorination reactions involved in the sequential dechlorination pathways of hexachlorobenzene to benzene. The logK values, which range between 8.7 and 11.5, decrease with the number of chlorine atoms carried by the benzene ring, meaning that dechlorination becomes (slightly) less favourable when the number of chlorine substituents decreases. Dehalococcoides sp. strain CBDB1 is an example of an organism that can grow with chlorinated benzenes as electron acceptor (Adrian et al. 2000; Lorah and Olsen, 1999). Presently the only chlorinated benzene congener that appears to resist being dehalorespired is monochlorobenzene. There is however no thermodynamic reason why microorganisms should not be able to grow with this compound as electron acceptor: the hunt is on (Fung et al. 2009).

Dichloroelimination is a special case of reductive dechlorination, where two chloral substituents are removed from adjacent carbon atoms, while the aliphatic C-C bond is converted into an unsaturated $\mathrm{C}=\mathrm{C}$ bond (Fig. 5, Dolfing, 2000). This reaction is of particular environmental relevance: the first step in the degradation of the organochlorine lindane ( $\gamma^{-}$hexachlorocyclohexane) is a dihaloelimination to $\gamma$-3,4,5,6-tetrachloro-1cyclohexene (Heritage and Mac Rae 1997; Lal et al. 2010). Also, Lorah and Olsen (1999) have observed that in a freshwater tidal wetland degradation of 1,1,2,2-tetrachloroethane involved formation of 1,2-dichloroethylene rather than only classical reductive 


\begin{tabular}{|c|c|c|}
\hline $1 / 2$ hexachlorobenzene $+1 / 2 \mathrm{H}^{+}+\mathrm{e}^{-}$ & $=1 / 2$ pentachlorobenzene $+1 / 2 \mathrm{Cl}^{-}$ & 11.53 \\
\hline \multirow[t]{3}{*}{$1 / 2$ pentachlorobenzene $+1 / 2 \mathrm{H}^{+}+\mathrm{e}^{-}$} & $=1 / 21,2,3,4$-tetrachlorobenzene $+1 / 2 \mathrm{Cl}^{-}$ & 10.63 \\
\hline & $=1 / 21,2,3,5$-tetrachlorobenzene $+1 / 2 \mathrm{Cl}^{-}$ & 11.21 \\
\hline & $=1 / 21,2,4,5$-tetrachlorobenzene $+1 / 2 \mathrm{Cl}^{-}$ & 10.83 \\
\hline \multirow[t]{2}{*}{$1 / 21,2,3,4$-tetrachlorobenzene $+1 / 2 \mathrm{H}^{+}+\mathrm{e}^{-}$} & $=1 / 21,2,3$-trichlorobenzene $+1 / 2 \mathrm{Cl}^{-}$ & 10.11 \\
\hline & $=1 / 21,2,4$-trichlorobenzene $+1 / 2 \mathrm{Cl}^{-}$ & 11.10 \\
\hline \multirow[t]{3}{*}{$1 / 21,2,3,5$-tetrachlorobenzene $+1 / 2 \mathrm{H}^{+}+\mathrm{e}^{-}$} & $=1 / 21,2,3$-trichlorobenzene $+1 / 2 \mathrm{Cl}^{-}$ & 9.54 \\
\hline & $=1 / 21,3,5$-trichlorobenzene $+1 / 2 \mathrm{Cl}^{-}$ & 10.84 \\
\hline & $=1 / 21,2,4$-trichlorobenzene $+1 / 2 \mathrm{Cl}^{-}$ & 10.53 \\
\hline $1 / 21,2,4,5$-tetrachlorobenzene $+1 / 2 \mathrm{H}^{+}+\mathrm{e}^{-}$ & $=1 / 21,2,4$-trichlorobenzene $+1 / 2 \mathrm{Cl}^{-}$ & 10.91 \\
\hline \multirow[t]{2}{*}{$1 / 2$ 1,2,3-trichlorobenzene $+1 / 2 \mathrm{H}^{+}+\mathrm{e}^{-}$} & $=1 / 21,2$-dichlorobenzene $+1 / 2 \mathrm{Cl}^{-}$ & 10.41 \\
\hline & $=1 / 21,3$-dichlorobenzene $+1 / 2 \mathrm{Cl}^{-}$ & 10.64 \\
\hline \multirow[t]{3}{*}{$1 / 21,2,4$-trichlorobenzene $+1 / 2 \mathrm{H}^{+}+\mathrm{e}^{-}$} & $=1 / 21,2$-dichlorobenzene $+1 / 2 \mathrm{Cl}^{-}$ & 9.42 \\
\hline & $=1 / 21,3$-dichlorobenzene $+1 / 2 \mathrm{Cl}^{-}$ & 9.65 \\
\hline & $=1 / 21,4$-dichlorobenzene $+1 / 2 \mathrm{Cl}^{-}$ & 9.96 \\
\hline $1 / 2$ 1,3,5-trichlorobenzene $+1 / 2 \mathrm{H}^{+}+\mathrm{e}^{-}$ & $=1 / 21,3$-dichlorobenzene $+1 / 2 \mathrm{Cl}^{-}$ & 9.33 \\
\hline $1 / 2$ 1,2-dichlorobenzene $+1 / 2 \mathrm{H}^{+}+\mathrm{e}^{-}$ & $=1 / 2$ monochlorobenzene $+1 / 2 \mathrm{Cl}^{-}$ & 9.94 \\
\hline $1 / 21,3$-dichlorobenzene $+1 / 2 \mathrm{H}^{+}+\mathrm{e}^{-}$ & $=1 / 2$ monochlorobenzene $+1 / 2 \mathrm{Cl}^{-}$ & 9.71 \\
\hline $1 / 21,4$-dichlorobenzene $+1 / 2 \mathrm{H}^{+}+\mathrm{e}^{-}$ & $=1 / 2$ monochlorobenzene $+1 / 2 \mathrm{Cl}^{-}$ & 9.40 \\
\hline $1 / 2$ monochlorobenzene $+1 / 2 \mathrm{H}^{+}+\mathrm{e}^{-}$ & $=1 / 2$ benzene $+1 / 2 \mathrm{Cl}^{-}$ & 8.75 \\
\hline
\end{tabular}

Table 5. Redox half-reactions for reductive dechlorination of hexachlorobenzene to benzene and their $\operatorname{logK}$ at $25^{\circ} \mathrm{C}$. Free energy $\left(\mathrm{G}_{\mathrm{f}}{ }^{\circ}\right)$ data are from Dolfing and Harrison (1992) and Stumm and Morgan (1996), in $\mathrm{kJmol}^{-1}$ : hexachlorobenzene $=46.0 ;$ pentachlorobenzene $=$ $45.7 ; 1,2,3,4$-tetrachlorobenzene $=55.8 ; 1,2,3,5$-tetrachlorobenzene $=49.2 ; 1,2,4,5$ -

tetrachlorobenzene $=53.5 ; 1,2,3$-trichlorobenzene $=71.7 ; 1,2,4$-trichlorobenzene $=60.5$; 1,3,5-trichlorobenzene $=56.8 ; 1$,2-dichlorobenzene $=84.3 ; 1,3$-dichlorobenzene $=81.8 ; 1,4$ dichlorobenzene $=78.3 ;$ monochlorobenzene $=102.3 ;$ benzene $=133.8 ; \mathrm{Cl}^{-}=-131.3 ; \log \mathrm{K}$ $=-\left(\Delta G^{\circ}\right.$ r $) / R T \ln (10)$. For sample calculation see footnote to Table 2 .

dechlorination to lesser chlorinated ethanes. This is unfortunate as subsequent anaerobic degradation of dichloroethylene will give rise to the formation of vinyl chloride, a notorious carcinogen. The energy yield per mole of reducing equivalents used for dihaloeliminations is higher than the yield for the corresponding classical hydrogenolysis reactions (Dolfing, 2000) which suggests that where possible this pathway is especially important under conditions where competition for reducing equivalents is fierce.

A prime example of anaerobic in situ degradation of a pesticide in anaerobic sediments has been reported for Lake Ketelmeer in the Netherlands (Beurskens et al. 1993). This lake acts as a sedimentation area for the suspended solids from the river Rhine. Comparison of recent and archived core layers revealed a $80 \%$ loss of hexachlorobenzene and increases in 1,3,5trichlorobenzene and 1,3-dichlorobenzene during the 20 years of "in situ" incubation. Laboratory incubations with these sediments demonstrated that the native microbial population was catalyzing this reaction and that the organisms involved selectively 
mediated the thermodynamic most favourable reactions (Beurskens et al. 1994). Indeed, thermodynamics has been used successfully to rationalize dechlorination and dechlorination patterns of organohalogens, but this approach does not always work (Dolfing, 2003). Thus there is a need for more than "just" thermodynamics to explain and predict the dechlorination (patterns) or the lack thereof in Nature. With some unfortunate exceptions pesticides concentrations in the environment are relatively low. Hence it seems plausible that Nature needs time to respond to the challenge to use these compounds efficiently, which is as energy source. Meanwhile co-metabolism may well be the route that nature uses to cleanse itself slowly but steadily. Even for the relative success story of hexachlorobenzene degradation in Rhine sediments its estimated half life was seven years (Beurskens et al. 1993).

\section{In situ observations of consortia biodegradation efficiency}

Euphemistically, margin growth for herbicides in situ biodegradation knowledge remains important. Bromoxynil, dicamba, 2-4D and atrazine are the only herbicides whose degradation has been substantially studied in vitro, and data illustrate the pertinence of electron-acceptor consortium segregation approach.

Bromoxynil is aerobically degraded into 3,5-dibromo-4-hydroxybenzonitrile. Knight et al. (2003) estimated the microbial degradation under denitrifying, Fe(III)-reducing, sulfidogenic while 140 days are not enough to observe a significant degradation under denitrifying conditions, bromoxynil is degraded much faster (40d) under more reduced conditions.

Dicamba anaerobic metabolisation produces 3,6-dichlorosalicylate that is in turn transformed under methanogenic conditions by O-demethylation in 6-chlorosalycilate. Unfortunately, those dicamba metabolites accumulate and, as for bromoxynil, their degradation seems to be drastically less under denitrifying conditions. However, in sediment, 3- and 5-chlorosalycilate are degraded under denitrifying conditions, revealing that the position of the chlorine substituent is key for chlorosalicylates degradation in anoxic environments (Milligan \& Häggblom, 2001). In sediment, methanogenic consortia are able to degrade all the halogenated dicamba metabolites, but under sulphate- and Fe(III)- reducing conditions micro-organisms are not able to do so, except for the final dechlorined metabolite (salycilate). Milligan and Häggblom (2001) highlight that sediment ability is due to specific consortia: the same experiment on agricultural soil did not show any dehalogenation.

Not all sediment floras are the same, though. For atrazine for example, Crawford et al. (1998) use the presence of indigenous organisms capable of anaerobic atrazine biodegradation as explanation for the observation that inoculation of a denitrifying bacterium cleaving the triazine ring enhance the anaerobic mineralization of atrazine compared to a non inoculated sediment. However, Devault et al. $(2009,2010)$, comparing in situ early diagenesis and herbicide vertical profile did not find any evidence of atrazine degradation under the considered environmental conditions.

Briefly, notwithstanding consortia abilities, biodegradation is theoretically proportional to energy yield. However, as explained above, microbial degradation of persistent pesticides tends to increase with decreasing redox potential when dehalogenation processes involving anaerobic enzymes are involved: thus biotransformation of organohalide contaminants in situ will vary as a function of the redox conditions within the electron acceptor profile (Häggblom et al., 2003b; Kuhn et al., 1990; Colberg, 1991). 
Biodegradation efficiency depends on:

- Presence of organic carbon. Enrichment of sediment induces an early diagenesis increase (Crawford et al., 1998, Walker et al., 2001).

- Local flora. Consequently, each sediment consortia should be characterised to estimate the degradation efficiency. Inoculating is an alternative to give ability to the local biota (Goux et al., 2000).

- The enzymatic set of each electron-acceptor segregated consortia. By the way, some consortia could be the less effective for a chemical family and being the most effective for another.

- Molecule characteristics as conformation influences the degradation efficiency (Milligan \& Häggblom, 2001).

Even if early diagenesis is underestimated process, in situ relating metabolisation could lead to a metabolic deadlock and metabolite accumulation (harmlessness to proven). Moreover, degradation by consortia involved in early diagenesis could be effective for molecules considered as non-degradable as 6-chlorosalycilate -but metabolic pathways are mostly unknown due the lack of early diagenesis consideration.

- $\mathrm{pH}$ and redox modification that could modify the sorption of molecules: even if chemicals are not degraded, their sorption could be modified directly (Morillo et al., 1997, for glyphosate and Hermosin \& Cornejo, 1993, for 2-4D) or indirectly -due to desorption of desorbing promoters like Fe(II) (Klupinski \& Chin, 2003) or Cu(II) for glyphosate (Morillo et al., 1997). Desorption could facilitate biodegradation too (Walker et al., 2001) and, therefore has a major effect on herbicide fate (Daniels et al, 2000).

In the field, early diagenesis is influenced by electron acceptor abundance. Nitrogen fertilisers are widely used in the same agricultural areas where herbicides are spread. Denitrifying activity is so reported as a major anaerobic condition in fresh water sediments (Camargo \& Alonso, 2006), which may be beneficial for atrazine removal (Crawford et al. 1998). Inversely, since sulphate reducers competitively scavenge reducing equivalents, reductive dehalogenation is often inhibited in the presence of sulphate; as this has been observed in practice in methanogenic systems (Townsend et al., 1997; Kuhn, 1990). However, microbial degradation process of organohalogens under sulphate-reduction conditions has also been reported, as for example in the case of 2-4 dichlorophenoxyacetic acid (2,4 D) (Boyle et al., 1999). Such occurrences depend on the autochthonous microbial populations, and the degree to which these populations leave space and opportunities for incoming foreign microbes to handle contaminants (Goux et al., 2000). Inversely, herbicide presence could inhibit flora as reported by Isolda \& Hayasaka (1991) for simazine or Crawford et al., (1998) for atrazine. However, those observations could be propitious for a feed-back effect (Laursen \& Carlton, 1999): herbicide presence could inhibit consortia activities.

The previous observations however should not give rise to premature optimism. For instance, early diagenesis consortia had no observable effect on herbicide degradation in the sediments of an intensive agricultural area where s-triazines, substituted ureas and chloroacetanilides where widely spread (Devault et al., 2009). Considering sedimentation and erosion events, coring needs an optimal knowledge on the sampling place. Interpolating half-life of herbicides in soils and herbicide profiles could inform on the degradation length but important sedimentation rate induces a rapid evolution of lain matters from aerobic condition to methanogenesis ones. By the way, if degradation is not obvious, it inform about the longer remanence of studied herbicides in sediment than in soils. Moreover, it illustrates the threat of enhanced erosion: under the methanogenic condition reigns abiotic degradation 
and desorption (Arildskov et al., 2001). If degradation is observed in the lab for some consortia, field studies are still too scarce to ensure representativeness and the kinetics of insitu degradation remains to establish.

\section{Perspectives}

Scientific literature about the in situ biodegradation of herbicides in sediments is still limited but the increase of their release in the environment should highlight sediment as biodegrading matrix. Coring in order to extrapolate the ancient fluxes, as it was used for the nowadays banned persistent organic pollutants (POPs), is becoming obsolete considering the emergence of new molecules with short half-life, especially herbicides. Instead of being considered as an inert matrix of POPs settling and archiving, sediment role into biodegradation of emergent pollutants should be increasingly taken into account. Herbicide degradation in sediment with depth could be considered as a screening of metabolisation efficiency of segregated consortia. Generalisation of interpretation of vertical profile or inlab metabolisation testing could allow to find consortia able to degrade herbicides and to use them as inocula for the bioremediation of contaminated areas or to determine the fate of chemicals in lake, lentic and marine area, where contaminated sediment management becomes of increasing concern.

\section{References}

Adrian, L., Szewzyk, U., Wecke, J. \& Gorisch, H. (2000). Bacterial dehalorespiration with chlorinated benzenes. Nature Vol. 408, 580-583.

Alavanja, M.C.R. (2009). Introduction: Pesticides use and exposure extensive worldwide. Reviews on Environmental Health Vol. 24, No. 4, pp. 303-309

Aller, R.C. (1977). The influence of macrobenthos on the chemical diagenesis of marine sediments. Ph.D. thesis. Yale University.

Aller, R.C., (1980). Quantifying solute distributions in the bioturbated zone of marinesediments by defining an average micro-environment. Geochimica et Cosmochimica Acta, Vol. 44, 1955-1965.

Aller, R.C. (1982). The effects of macrobenthos on chemical properties of marine sediment and overlying water. In: Animal-Sediment relations. Eds P.L. McCall and M.J.S. Tevest, Plenum, N.Y., 53-102.

Aller R.C. (1990) Bioturbation and manganese cycling in hemipelagic sediments. Philosophic Transactions of Royal Society of London. A, Vol. 331, 51-68.

Aller, R.C. (1994). Bioturbation and remineralization of sedimentary organic matter: effects of redox oscillation. Chemical Geology, Vol. 114, 331-345.

Aller R.C., Hall P.O.J., Rude P.D., Aller J.Y. (1998) Biogeochemical heterogeneity and suboxic diagenesis in hemipelagic sediments of the Panama Basin. Deep-Sea Research part 1, 45, 133-165.

Anschutz, P., Zhong, S., Sundby, B., Mucci, A., Gobeil, C. (1998). Burial efficiency of phosphorus and the geochemistry of iron in continental margin sediments. Limnology and Oceanography, Vol. 43, No 1, 53-64. 
Anschutz, P., Sundby, B., Lefrançois, L., Luther III, G.W., Mucci, A. (2000). Interactions between metal oxides and species of nitrogen and iodine in bioturbated marine sediments Geochimica et Cosmochimica Acta, Vol. 64, No 16, 2751-2763.

Anschutz P., Dedieu K., Desmazes F. Chaillou G. (2005) Solid speciation, oxidation state, and reactivity of manganese in marine sediments. Chemical Geology, Vol. 281, 265279.

Arildskov, N.P., Pedersen, P.G. \& Albrechtsen, H.-J., (2001). Fate of the herbicides 2,4,5-T, atrazine, and DNOC in a shallow, anaerobic aquifer investigated by in situ passive diffusive emitters and laboratory batch experiments, Ground Water, Vol. 39, No. 6, 819-830

Banta, G.T. \& Andersen O. (2003). Bioturbation and the fate of sediment pollutants. Vie Milieu, Vol. 53, 233-248.

Bartha, R. (1971). Metabolism of the herbicide pronamide in soil. Journal of Agricultural And Food Chemistry, Vol. 19, No. 2, 385-387.

Berner R.A. (1971). Principles of Chemical Sedimentology. Mc Graw-Hill Book Co. 240p.

Berner, R.A. (1980). Early Diagenesis: A Theoretical Approach. Princeton University Press. 260pp.

Beurskens, J.E.M., Dekker, C.G.C., Jonkhoff, J. \& Pompstra, L. (1993) Microbial dechlorination of hexachlorobenzene in a sedimentation area of the Rhine river. Biogeochemistry Vol. 19, 61-81.

Beurskens, J.E.M., Dekker, C.G.C., van den Heuvel, H., Swart, M., de Wolf, J. \& Dolfing, J. (1994). Dechlorination of chlorinated benzenes by an anaerobic microbial consortium that selectively mediates the thermodynamic most favorable reactions. Environmental Science \& Technology, Vol. 28, 701-706.

Boudreau, B.P. (1986a). Mathematics of tracer mixing in sediments: I. Spatially-dependent, diffusive mixing. American Journal of Sciences, Vol. 286, 161-198.

Boudreau, B.P. (1986b). Mathematics of tracer mixing in sediments: II. Nonlocal mixing and biological conveyor-belt phenomena. American Journal of Sciences, Vol. 286, 199-238.

Boudreau, B.P. (1996). A method-of-lines code for carbon and nutrient diagenesis in aquatic sediments. Comp. Geosc., 22, 479-496.

Boudreau, B.P. (2004). What controls the mixed-layer depth in deep-sea sediments? The importance of POC flux - COMMENT. Limnology and Oceanography, Vol. 49,620-622.

Boyle, A.W., Knight, V.K., Häggblom, M.M. \& Young, L.Y. (1999). Transformation of 2,4dichlorophenoxyacetic acid in four different marine and estuarine sediments: Effects of sulphate, hydrogen and acetate on dehalogenation and side-chain cleavage. FEMS Microbiology Ecology, Vol. 29, No1, 105-113.

Brinkhurst, R.O., Chua, K.E. \& Kaushik, N.K. (1972). Interspecific interactions and selective feeding by tubificid oligochaetes. Limnology and Oceanography Vol. 17, 122-133.

Camargo, J.A. \& Alonso, Á. (2006). Ecological and toxicological effects of inorganic nitrogen pollution in aquatic ecosystems: A global assessment. Environment International. Vol. 32, No. 6 831-849.

Canavan, R.W., Slomp, C.P., Jourabchi, P., Van Cappelen, P., Laverman, A.M. \& Van Den Berg, G.A. (2006). Organic matter mineralization in sediment of a coastal freshwater lake and response to salinization. Geochimica Cosmochimica Acta, 90, 2836-2855. 
Canfield, D.E., Raiswell, R., Bottrell, S. (1992). The reactivity of sedimentary iron minerals toward sulfide. American Journal of Science, Vol. 292, No. 9, 659-683.

Canfield, D.E., Thamdrup, B., Hansen, J.W., (1993). The anaerobic degradation of organic matter in Danish coastal sediments: Iron reduction, manganese reduction and sulfate reduction. Geochimica Cosmochimica Acta 57 (16), 3867-3883.

Chaillou, G., Anschutz, P., Dubrulle, C., Lecroart, P. (2007). Transient states in diagenesis following the deposition of a gravity layer: Dynamics of O2, Mn, Fe and N-species in experimental units. Aquatic Geochemistry, Vol. 13, No 2, 157-172.

Ciarelli, S., Van Straalen, N.M., Klap, V.A. \& Van Wezel, A.P. (1999). Effects of sediment bioturbation by the estuarine amphipod Corophium volutator on fluoranthene resuspension and transfer into the mussel (Mytilis edulis). Environmental. Toxicology and Chemistry, Vol. 18, 318-328.

Ciutat, A., Anschutz P., Gerino, M., \& Boudou, A. (2005). Effects of bioturbation on cadmium transfer and distribution into freshwater sediments. Environmental Toxicology and Chemistry, Vol. 24, 1048-1058.

Ciutat, A., Weber, O., Gerino, M. \& Boudou, A. (2006). Stratigraphic effects of tubificids in freshwater sediments: a kinetic study based on X-ray images and grain-size analysis. Acta Oecologica, Vol. 30, 228-237.

Colberg, 1991

Connor, S.E., Thomas, I. (2003). Sediments as archives of industrialisation: evidence of atmospheric pollution in coastal wetlands of southern Sydney, Australia. Water, Air and Soil Pollution, Vol. 149, 189-210.

Covaci, A., Gheorghe, A., Voorspoels, S., Maervoet, J., Steen Redeker, E., Blust, R. \& Schepens, P. (2005). Polybrominated diphenyl ethers, polychlorinated biphenyls and organochlorine pesticides in sediment cores from the Western Scheldt river (Belgium): analytical aspects and depths profiles. Environmental International, Vol. 31, 367-375.

Crawford, J.J., Sims, G.K., Mulvaney, R.L. Radosevich, M. (1998). Biodegradation of atrazine under denitrifying conditions. Applied Microbiology and Biotechnology Vol. 49, No. 5, $1998,618-623$

Daniels, W.M., House, W.A., Rae, J.E. \& Parker, A. 2000. The distribution of micro-organic contaminants in river bed-sediment cores. Science of the Total Environment, Vol. 253, No. 1-3, 15, 81-92.

Darwin, C. (1881). The formation of vegetable mould through the action of worms with observation of their habits. John Murray.

Davis, R.B. (1974). Stratigraphic effects of tubificids in profundal lake sediments. Limnogy and Oceanography, Vol. 19, 466-488.

De Deckere, E. M. G. T, Tolhurst, T. J. \& De Brouwer, J. F. C. (2001). Destabilization of Cohesive Intertidal Sediments by Infauna. Estuarine and Coastal Shelf Sciences, Vol. 53, 665-669.

Deflandre, B., Mucci, A., Gagné, J.-P., Guignard, C., Sundby, B.jorn (2002). Early diagenetic processes in coastal marine sediments disturbed by a catastrophic sedimentation event. Geochimica et Cosmochimica Acta, Vol. 66, No 14, 2547-2558.

De Lange, G.J. (1986). Early diagenetic reactions in interbedded pelagic and turbiditic sediments in the Nares Abyssal Plain (western North Atlantic): Consequences for 
the composition of sediment and interstitial water. Geochimica et Cosmochimica Acta, Vol. 50, No 12, 2543-2561.

Delmotte, S. (2007). Role of bioturbation in the biogeochemical functioning of the sedimentwater interface : Modelling the diversity of biological transports and the effects on the early diagenesis within the sediments of a freshwater reservoir. Ph.D. Dissertation, Toulouse University, France, 2007.

Delmotte, S., Meysman, F.J.R, Ciutat, A., Sauvage, S., Boudou, A. \& Gerino, M. (2007). Cadmium transport in sediments by tubificid bioturbation: an assessment of model complexity. Geochimica Cosmochimica Acta , Vol. 71, 844-862.

Delmotte, S. Gerino, M., Thebault, J-M. \& Meysman, F.J.R. (2008). Modeling effects of patchiness and biological variability on transport rates within bioturbated sediments. Journal of Marine Research, Vol. 66, 191-218.

Devault, D.A., Delmotte, S., Merlina, G., Lim, P., Gerino \& M., Pinelli, E. (2009). Influence of in situ biological activity on the vertical profile of pre-emergence herbicides in sediment. Journal of Environmental Monitoring, Vol. 11, No 6, 1206-1215.

Devault, D.A., Ith, C., Merlina, G., Lim, P. \& Pinelli, E. (2010). Study of a vertical profile of pre-emergence herbicide contamination in middle Garonne sediments. International Journal of Environmental Analytical Chemistry, Vol. 90, No. 3-6, 311-320.

de Wit C.A., Alaee M., Muir D.C.G. 2006. Levels and trends of brominated flame retardants in the Arctic. Chemosphere 64, pp. 209-233.

Dolfing, J. \& Tiedje, J.M. (1986). Hydrogen cycling in a three-tiered food web growing on the methanogenic conversion of 3-chlorobenzoate. FEMS Microbiology Ecology, Vol.38, 293-298.

Dolfing, J. (1990). Reductive dechlorination of 3-chlorobenzoate is coupled to ATP production and growth in an anaerobic bacterium, strain DCB-1. Archives of Microbiology, Vol. 153, 264-266.

Dolfing, J. \& Harrison , B. K. (1992). Gibbs free energy of formation of halogenated aromatic compounds and their potential role as electron acceptors in anaerobic environments. Environmental Science \& Technology, Vol. 26, 2213-2218.

Dolfing, J. (2000). Energetics of anaerobic degradation pathways of chlorinated aliphatic compounds. Microbial Ecology, Vol. 40, 2-7.

Dolfing, J. (2003). Thermodynamic considerations for dehalogenation. In: Dehalogenation: Microbial Processes and Environmental Applications (M.M. Häggblom and I.D. Bossert eds.), 89-114, Kluwer Academic Publishers, Boston, MA, USA,.

Dolfing, J., van Eekert, M., Seech, A., Vogan, J. \& Mueller, J. (2008). In situ chemical reduction technologies: Significance of low Eh reactions. Soil $\mathcal{E}$ Sediment Contamination Vol. 17, 63-74.

Eganhouse, R.P., Pontolillo, J. \& Leiker, T.J. (2000). Diagenetic fate of organic contaminants on the Palos Verdes Shelf, California. Marine Chemistry, Vol. 70, No. 4, 289-315.

Feng, H., Cochran K., Lwiza H., Brownawell, B.J. \& Hirschberg, D.J. (1998). Distribution of heavy metal and PCB contaminants in the sediments of an urban estuary: the Hudson river. Marine Environmental Research, Vol. 45, No. 1, 68-88.

Fisher, J.D. (1974). Fate of herbicide-derived chloroanilines in soil.. Journal of Agricultural and Food Chemistry, Vol. 22, No. 4, 606-608. 
Froelich, P.N., Klinkhammer, G.P., Bender, M.L., Luedtke, N.A., Heath, G.R., Cullen, D., Dauphin, P., Hammond, D., Hartman, B. \& Maynard, V. (1979). Early oxidation of organic-matter in pelagic sediments of the Eastern Equatorial Atlantic- suboxic diagenesis. Geochimica et Cosmochimica Acta, 43, 1075-1090.

Fung, J.M., Weisenstein, B.P., Mack, E.E., Vidumsky, J.E., Ei T.A. \& Zinder, S.H. (2009). Reductive dechlorination of dichlorobenzenes and momochlorobenzene to benzene in microcosms. Environmental Science and Technology, Vol. 43, 2302-2307.

Gerino, M. (1990). The effects of bioturbation on particle redistribution in Mediterranean coastal sediment. Preliminary result. Hydrobiologia, Vol. 207, 251-258

Gerino, M., Aller, R.C., Lee, C., Cochran, J.K., Aller, J.Y, Green, M.A. \& Hirschberg, D. (1998). Comparison of different tracers and methods used to quantify bioturbation during a spring bloom: 234 Thorium, luminophores and Chlorophyll a. Estuarine and Costal Shelf Sciences, Vol. 15, 1483-1496.

Gibson, S.A., Suflita, J.M. (1990). Anaerobic biodegradation of 2,4,5-trichlorophenoxyacetic acid in samples from a methanogenic aquifer: Stimulation by short-chain organic acids and alcohols. Applied and Environmental Microbiology, Vol. 56, No 6, 1825-1832.

Gilbert, F., Hulth, S. \& Aller, R.C. (2003a). The influence of macrofaunal burrow spacing and diffusive scaling on sedimentary nitrification and denitrification: An experimental and model approach. Journal of Marine Research, Vol. 61, 101-125.

Gilbert, F., Hulth, S., Stroemberg, N., Ringdahl, K. \& Poggiale J.C. (2003b) 2-D optical quantification of particle reworking activities in marine surface sediments. Journal of Experimental Marine Biology and Ecology, Vol. 285/286, 251-263.

Goldberg, E. D. \& Koide, M. (1962). Geochronological studies of deep-sea sediments by the Io/Th method. Geochimica et Cosmochimica Acta, Vol. 26, 417-450.

Goux, S.J., Ibanez, M., Van Hoorick, M. Debongnie, P., Agathos, S.N., Pussemier, L. 2000. Biodegradation of atrazine in sand sediments and in a sand-filter. Applied Microbiology and Biotechnology, Vol. 54, No. 4, 589-596.

Gray, J.S. (1974). Animal sediment relationship. Oceanographic and Marine Biology Revue, Vol. 12, 223-261.

Grimalt, J.O., van Drooge, B.L., Ribes A., Vilanova, R.M., Fernandez, P. \& Appleby, P. (2004). Persistent organochlorine compounds in soil and sediments of European high altitude mountain lakes. Chemosphere, Vol. 54, 1549-1561.

Grover, R., Wolt, J.D., Cessna, A.J. \& Schiefer, H.B. (1997). Environmental fate of trifluralin. Reviews of Environmental Contamination and Toxicology, Vol. 153, 1-64.

Guinasso, N.L. \& Schink, D.R. (1975). Quantitative estimates of biological mixing rates in abyssal sediments. Journal of Geophysical Research, Vol. 80, 3032-3043.

Häggblom, M.M. and Bossert, I.D. (2003). Halogenated compounds - A global perspective. In: Dehalogenation: Microbial Processes and Environmental Applications (M.M. Häggblom and I.D. Bossert eds.). Kluwer Academic Publishers, Boston, MA, USA, pp. 3-29.

Häggblom, M.M., Ahn, Y.-B., Fennell, D.E., Kerkhof, L.J. \& Rhee, S.-K. (2003b). Anaerobic Dehalogenation of Organohalide Contaminants in the Marine Environment. Advances in Applied Microbiology, Vol. 53, 61-84.

Harrad, S.J., Sewart, A.P., Alcock, R., Boumphrey, R., Burnett, V., Duatrte-Davidson, R., Halsall, C., Sanders, G., Waterhouse, K., Wild, S.R. \&, Jones K.C. (1994). 
Polychlorinated biphenyls (PCB) in the British environment: sinks, sources and temporal trends. Environmental Pollution, Vol. 85, 131-146.

Heritage, A.D. \& Mac Rae, I.C. (1977). Identification of intermediates formed during the degradation of hexachlorocyclohexanes by Clostridium sphenoides. Applied and Environmental Microbiology, Vol. 33, 1295-1297.

Hermosin, M.C. \& Cornejo, J. 1993. Binding mechanism of 2,4-dichlorophenoxyacetic acid by organo-clays. Journal of Environmental Quality, Vol. 22, No. 2, 325-331

Hoehler, T.M., Alperin, M.J., Albert, D.B. \& Martens, C.S. (2001). Apparent minimum free energy requirements for methanogenic archaea and sulphate-reducing bacteria in an anoxic marine sediment. FEMS Microbiology Ecology, Vol 38, 33-41.

Hong, S.H., Yim U.H., Shim, W.J., Oh, J.R. \& Lee, I.S. (2003). Horizontal and vertical distribution of PCBs and chlorinated pesticides in sediments from Masan Bay, Korea. Marine Pollution Bulletin, Vol. 46, 244-253.

Hulth, S., Aller, R.C., Gilbert, F. (1999). Coupled anoxic nitrification/manganese reduction in marine sediments. Geochimica et Cosmochimica Acta. Vol. 63, No 1, 49-66.

Hyacinthe, C., Anschutz, P., Carbonel, P., Jouanneau, J.-M., Jorissen, F.J. (2001). Early diagenetic processes in the muddy sediments of the Bay of Biscay. Marine Geology, Vol. 177, No 1-2, 111-128.

Isolda, A. \& Hayasaka, S.S. 1991. Effect of herbicide residues on microbial processes in pond sediment. Archives of Environmental Contamination and Toxicology. 20, 1, 81-86

Jablonski, P.E. \& Ferry, J.G. (1992). Reductive dechlorination of trichloroethylene by the COreduced $\mathrm{CO}$ dehydrogenase enzyme complex from Methanosarcina thermophila. FEMS Microbioloy Letters, Vol. 96, 55-60.

Jablonski, P.E., Phaesant, D.J. \& Ferry, J.G. (1996). Conversion of Kepone by Methanosarcina thermophila. FEMS Microbioloy Letters, Vol. 139, 169-173.

Jayachandran, G., Görisch, H. \& Adrian, L. (2003). Dehalorespiration with hexachlorobenzene and pentachlorobenzene by Dehalococcoides sp. strain CBDB1. Archives of Microbiology, Vol. 180, 411-416.

Jorgensen 1982

Klupinski, T.P. \& Chin, Y.-P. (2003). Abiotic degradation of trifluralin by Fe(II): kinetics and transformation pathways. Environmental Science \& Technology, Vol. 37, 1311-1318.

Knight, V.K., Berman, M.H. \& Häggblom, M.M. 2003. Biotransformation of 3,5-dibromo-4hydroxybenzonitrile under denitrifying, Fe(III)-reducing, sulfidogenic, and methanogenic conditions. Environmental Toxicology and Chemistry, Vol. 22, No. 3, 540-544.

Koistinen, J., Stenman, O., Haahti, H., Suonperä, M. \& Paasivirta, J. (1997). Polychlorinated diphenyl ethers, dibenzo-p-dioxins, dibenzofurans and biphenyls in seals and sediment from the Gulf of Finland. Chemosphere, Vol. 35, No. 6, 1249-1269.

Kristensen, E. \& Kostka, J.E. (2005). Macrofaunal burrows and Irrigation in marine sediment: microbiological and biogeochemical interactions. In Macro - and Microorganisms in Marine Sediments, Eds Kristensen E., Haese R.E., and Kostka J. E., American geophysical Union, p. 125-157.

Krutz, J.L., Shaner, D.L., Weaver, M.A., Webb, R.M.T., Zablotowicz, R.M., Reddy, K.N., Huang, Y. \& Thomson, S.J. (2010). Agronomic and environmental implications of enhanced s-triazine degradation. Pest Management Science, Vol. 66, No. 5, 461-481. 
Lal, R., Pandey, G., Sharma, P., Kumari, K., Malhotra, S., Pandey, R., Raina, V., Kohler, H.-P., Holliger, C., Jackson, C. \& Oakeshott, J.G. (2010). Biochemistry and microbial degradation of hexachlorocyclohexane and prospects for bioremediation. Microbiology and Molecular Biology Reviews, Vol. 74, 58-80.

Laursen, A.E., Carlton, R.G. (1999). Responses to atrazine of respiration, nitrification, and denitrification in stream sediments measured with oxygen and nitrate microelectrodes. FEMS Microbiology Ecology. Vol. 29, No. 3, 229-240.

Leuchs, V.H. (1986). The ventilation activity of Chironomus larvae (Diptera) from shallow and deep lakes and the resulting water circulation in correlation to temperature and oxygen conditions, Archives of Hydrobiology, Vol. 108, 281-299.

Lorah, M.M., Olsen, L.D. (1999). Natural attenuation of chlorinated volatile organic compounds in a freshwater tidal wetland: Field evidence of anaerobic biodegradation. Water Resources Research, Vol. 35, No 12, 3811-3827.

Löffler, F.A., Tiedje, J.M. \& Sanford, R.A. (1999). Fraction of electrons consumed in electron acceptor reduction and hydrogen thresholds as indicators of halorespiratory physiology. Applied and Environmental Microbiology, Vol. 64, 4049-4056.

Luther III G.W., Sundby B., Lewis B.L., Brendel P.J., Silverberg N., 1997. Interactions of manganese with the nitrogene cycle: Alternative pathways to dinitrogen. Geochimica Cosmochimica Acta, Vol. 61, 4043-4052.

Macdonald, W, Harner, T. \& Fyfe, J. (2005). Recent climate change in the Arctic and its impact on contaminant pathways and interpretation of temporal trend data. Science of the Total Environment, Vol. 342, 5-86.

Maphosa, F., de Vos, W.M. \& Smidt, H. (2010). Exploiting the ecogenomics toolbox for environmental diagnostics of organohalides-respiring bacteria. Trends in Biotechnology, Vol. 28, 308-316.

Maire, O., Lecroart, P., Meysman, F.J.R., Rosenberg, R., Duchene, J.C. \& Gremare, A. (2008). Methods of sediment reworking assessment in bioturbation research: a review. Aquatic Biology, Vol. 2, 219-238.

Matisoff, G. \& Wang, X. (1998). Solute transport in sediments by freshwater infaunal bioirrigators. Limnology and Oceanography, Vol. 43, 1487-1499.

McCall, P.L. \& Fisher, J.N. (1980). Effects of tubificids oligochaetes on physical and chemical properties of Lake Erie sediments. In Aquatic Oligochaete Biology. Edited by Brinkhurst R.O. and Cook D.G., pp253-318, Plenum, New York, 1980.

Meadows, P.S. \& Tait, J. (1989). Modification of sediment permeability and shear strength by two burrowing invertebrates. Marine Biology, Vol. 101, 75-82.

Mermillod-Blondin, F., Gaudet, J.P., Gerino, M., Desrosiers, G \& Des Chatelliers, M.C. (2003). Influence of macroinvertebrates on physico-chemical and microbial processes in hyporheic sediments. Hydrology Proceedings, Vol. 17, 779-794.

Meysman, F.J.R. (2001). Modelling the influence of ecological interactions on reactive transport processes in sediments. Ph.D. Dissertation, Ghent University, 2001.

Meysman, F.J.R., Boudreau, B.P. \& Middelburg, J.J. (2003). Relations between local, nonlocal, discrete and continuous models of bioturbation. Journal of Marine Research, Vol. 61, 391-410. 
Meysman, F.J.R., Middelburg, J.J. \& Heip, C.H.R. (2006a). Bioturbation: a fresh look at Darwin's last idea. Trends in Ecology and Evolution, Vol. 21, No. 12, 688-695.

Meysman, F.J.R., Galaktionov, O.S., Gribsholt, B. \& Middleburg, J.J. (2006b). Bio irrigation in permeable sediments: Advective pore-water transport induced by burrow ventilation. Limnology and Oceanography, Vol. 51, 142-156.

Meysman, F.J.R., Galaktionov, O.S., Cook, P.L.M., Janssen, F., Huettel, M., Middelburg, J.J. (2007). Quantifying biologically and physically induced flow and tracer dynamics in permeable sediments. Biogeosciences, Vol. 4, No. 4, 627-646.

Milligan, P.W. \& Häggblom, MM. (2001). Anaerobic degradation and dehalogenation of chlorosalicylates and salicylate under four reducing conditions. Biodegradation, Vol. 12, 159-167.

Mohn, W.W. \& Tiedje, J.M. (1992). Microbial reductive dehalogenation. Microbiology Revue, Vol. 56, 482-507.

Morillo, E., Undabeytia, T. \& Maqueda, C. (1997). Adsorption of glyphosate on the clay mineral montmorillonite: Effect of $\mathrm{Cu}(\mathrm{II})$ in solution and adsorbed on the mineral. Environmental Science and Technology, Vol. 31, No. 12, 3588-3592.

Mortensen, S.K. \& Jacobsen, C.S. (2004). Influence of frozen storage on herbicide degradation capacity in surface and subsurface sandy soils. Environmental Science and Technology, Vol.38, No. 24, 6625-6632.

Mortimer, R.J.G., Krom, M.D., Harris, S.J., Hayes, P.J., Davies, I.M., Davison, W., Zhang, H. (2002). Evidence for suboxic nitrification in recent marine sediments. Marine Ecology Progress Series, Vol. 236, 31-35.

Murray J.W., Codispoti L.A., Friederich G.E. (1995) Oxidation-reduction environments: The suboxic zone of the Black Sea. In Aquatic chemistry: Interfacial and Interspecies Processes (ed. C.P. Huang et al.) Vol. 244, 157-176. American Chemical Society.

Nylund, K, Asplund, L., Jansson, B. \& Jonnson, P. (1992). Analysis of some polyhalogenated organic pollutants in sediment and sewage sludge. Chemosphere, Vol. 24, No. 12, 1721-1730.

Petty, D.G., Getsinger, K.D., Woodburn, K.B. (2003). A review of the aquatic environmental fate of triclopyr and its major metabolites. Journal of Aquatic Plant Management, Vol. 41, No 2, 69-75.

Pignatello, J.J. (1992). Dark and photoassisted Fe3+-catalyzed degradation of chlorophenoxy herbicides by hydrogen peroxide. Environmental Science \& Technology, Vol. 26, No. 5, 944-951.

Rasmussen, A.D., Banta, G.T. \& Andersen, O. (1998). Effects of bioturbation by the lugworm Arenicola marina on cadmium uptake and distribution in sandy sediments. Marine Ecology Progress Series, Vol.164, 179-188.

Rawn, D.F.K., Lockhart, W.L., Wilkinson, P., Savoie, D.A., Rosenberg, G.B. \& Muir, D.C.G. (2001). Historical contamination of Yukon Lake sediment by PCBs and organochlorine pesticides: influence of local sources and watershed characteristics. The Science of the Total Environment, Vol. 280, 17-37.

Rhoads, D.C. (1974). Organism-sediment relations on the muddy sea floor. Oceanographic and Marine Biology Annual Revue, Vol. 12, 263-300. 
Rice D.L. (1986). Early diagenesis in bioadvective sediments: Relationships between the diagenesis of beryllium-7, sediment reworking rates, and the abundance of conveyor-belt deposit-feeders. Journal of Marine Research, Vol. 44, 149-184.

Roberts, T.R., Dyson, J.S., Lane \& M.C.G. (2002). Deactivation of the biological activity of paraquat in the soil environment: A review of long-term environmental fate. Journal of Agricultural and Food Chemistry, Vol. 50, No. 13, 3623-3631.

Robbins J.A., Kresoski J.R. \& Mozley S.C. (1977). Radioactivity in sediments of the Greats Lakes: post depositional redistribution by deposit-feeding organisms. Earth and Planetary Science Letters, Vol. 36, 325-333.

Schoonen, M.A.A., Barnes, H.L. (1991). Reactions forming pyrite and marcasite from solution: II. Via FeS precursors below $100^{\circ} \mathrm{C}$ Geochimica et Cosmochimica Acta, Vol. 55, No 6, 1495-1514.

Schulz H.D., Dahmke A, Schnizel U., Wallmann K., Zabel M. (1994) Early diagenetic processes, fluxes, and reaction rates in sediments of the South Atlantic. Geochimica et Cosmochimica Acta, Vol. 58, 2041-2060.

Secco T., Pellizzato F., Sfriso A., Pavoni B. (2005). The changing of contamination in the Lagoon of Venice. Part 1: organic pollutants. Chemosphere, Vol. 58, 279-290.

Self, R.F. and Jumars, P.A. (1978). New resource axes for deposit feeders. Journal of Marine Research, Vol. 36, 627-641.

Soetaert, K., Herman, P.M.J., Middleburg, J.J. (1996). A model of early diagenetic processes from the shelf to abyssal depths. Geochimica Cosmochimica Acta, Vol. 60, 1019-1040.

Stief, P. \& De Beer, D. (2002). Bioturbation effects of Chironomus riparius on the benthic Ncycle as measured using microsensors and microbiological assays. Aquatic Microbiology and Ecology, Vol. 27, 175-185.

Stumm W. and Morgan J. J. (1996). Aquatic chemistry. 3rd edition, J. Wiley and Sons, New York, 780p.

Sun, M.-Y., Aller, R.C., Lee, C. \& Wakeham, S.G. (2002). Effects of oxygen and redox oscillation on degradation of cell-associated lipids in surperficial marine sediments. Geochimica Cosmochimica Acta, Vol. 66, 2003-2012.

Sundby, B. (1977). Manganese-rich particulate matter in a coastal marine environment. Nature, Vol. 270, No 5636, 417-419.

Thullner, M., Van Cappellen, P. \& Regnier, P. (2005). Modeling the impact of microbial activity on redox dynamics in porous media. Geochimica Cosmochimica Acta, Vol. 21, 5005-5019.

Townsend, G.T., Ramanand, K. \& Suflita, JM. (1997). Reductive dehalogenation and mineralization of chlorobenzoate in the presence of sulphate by microorganisms from a methanogenic aquifer. Applied and Environmental Microbiology, Vol. 63, 27852791.

Van Cappellen, P. \& Wang, Y. (1995). Metal cycling in surface sediments: modeling the interplay of transport and reaction. In: Allen, H.E. (Ed.), Metal Contaminated Sediments. Ann Arbor Press, Chelsea, MI, 21-64.

van Eekert, M.H.A., Stams, A.J.M., Field, J.A. \& Schraa, G. (1999). Gratuitous dechlorination of chloroethanes by methanogenic granular sludge. Applied Microbiology and Biotechnology, Vol. 51: 46-52. 
Walker, A., Jurado-Exposito, M., Bending, G.D. \& Smith, V.J.R. (2001). Spatial variability in the degradation rate of isoproturon in soil. Environmental Pollution. Vol 111, No. 3, 407-415.

Wheatcroft, R.A., Jumars, P.A., Smith, C.R. \& Nowell, A.R.M. (1990). A mechanistic view of the particulate bio diffusion coefficient: step lengths, rest period and transport directions. Journal of Marine Research, Vol. 48, 177-207.

Wijsman, J.W.M., Herman, P.M.J., Middelburg, J.J. \& Soetaert, K. (2002). A model for early diagenetic processes in sediments of the continental shelf of the Black Sea. Estuarine and Coastal Shelf Science, Vol. 54, 403-421.

Wood, L.W. (1975). Role of oligochaetes in the circulation of water and solutes across the mud water interface. Verhandlungen der Internationalen Vereinigung fur Theoretische und Angewandte Limnologie, Vol. 19, 1530-1533. 


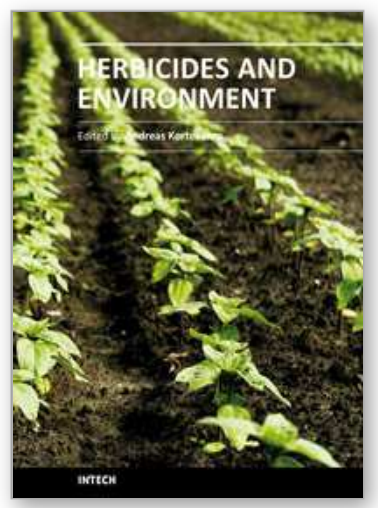

\author{
Herbicides and Environment \\ Edited by Dr Andreas Kortekamp
}

ISBN 978-953-307-476-4

Hard cover, 746 pages

Publisher InTech

Published online 08, January, 2011

Published in print edition January, 2011

Herbicides are much more than just weed killers. They may exhibit beneficial or adverse effects on other organisms. Given their toxicological, environmental but also agricultural relevance, herbicides are an interesting field of activity not only for scientists working in the field of agriculture. It seems that the investigation of herbicide-induced effects on weeds, crop plants, ecosystems, microorganisms, and higher organism requires a multidisciplinary approach. Some important aspects regarding the multisided impacts of herbicides on the living world are highlighted in this book. I am sure that the readers will find a lot of helpful information, even if they are only slightly interested in the topic.

\title{
How to reference
}

In order to correctly reference this scholarly work, feel free to copy and paste the following:

Devault Damien A., Delmotte Sébastien, Macarie Hervé, Dolfing Jan and Anschutz Pierre (2011). How Early Diagenesis Reveals in Situ Biodegradation of Herbicides in Sediment, Herbicides and Environment, Dr Andreas Kortekamp (Ed.), ISBN: 978-953-307-476-4, InTech, Available from:

http://www.intechopen.com/books/herbicides-and-environment/how-early-diagenesis-reveals-in-situbiodegradation-of-herbicides-in-sediment

\section{INTECH}

open science | open minds

\section{InTech Europe}

University Campus STeP Ri

Slavka Krautzeka 83/A

51000 Rijeka, Croatia

Phone: +385 (51) 770447

Fax: +385 (51) 686166

www.intechopen.com

\section{InTech China}

Unit 405, Office Block, Hotel Equatorial Shanghai

No.65, Yan An Road (West), Shanghai, 200040, China

中国上海市延安西路65号上海国际贵都大饭店办公楼 405 单元

Phone: +86-21-62489820

Fax: +86-21-62489821 
(C) 2011 The Author(s). Licensee IntechOpen. This chapter is distributed under the terms of the Creative Commons Attribution-NonCommercialShareAlike-3.0 License, which permits use, distribution and reproduction for non-commercial purposes, provided the original is properly cited and derivative works building on this content are distributed under the same license. 